\title{
Electrochemical Advanced Oxidation Processes: An Overview of the Current Applications to Actual Industrial Effluents
}

\author{
C. Barrera-Díaz, ${ }^{a}$ P. Cañizares, ${ }^{b}$ F. J. Fernández, ${ }^{b}$ R. Natividad, ${ }^{a}$ and M.A. Rodrigo ${ }^{b}, *$ \\ a Centro Conjunto de Investigación en Química Sustentable UAEM - UNAM, Carretera Toluca-Atlacomulco, km 14.5, Unidad \\ El Rosedal, C.P. 50200, Toluca, Estado de México, México. \\ b Department of Chemical Engineering, University of Castilla La Mancha, Campus Universitario s/n, 13071 Ciudad Real, \\ Spain. Manuel.Rodrigo@uclm.es
}

Received January 14 ${ }^{\text {th }}$, 2014; Accepted March 19 th 2014.

\begin{abstract}
Many human activities result in the production of wastewater. Usually, physical, chemical and biological processes are successfully combined for the treatment of municipal wastewater, attaining good removal efficiencies. However, some industrial processes introduce anthropogenic recalcitrant pollutants in wastewater that are quite difficult to remove or degrade using conventional means and that should be removed due to their hazardousness. In such cases, the application of an Advanced Oxidation Processes (AOP) uses to be a good and/or promising alternative to attain an appropriate effluent. These processes rely on generating hydroxyl radical, which is a powerful oxidant that mineralizes efficiently pollutants contained in wastewater. In this review, we focus on the use of electrochemical methods to produce hydroxyl radical, using directly or indirectly electrochemical technology, within the so-called Advanced Electrochemical Oxidation Processes (EAOP). These processes include electrochemical, sonoelectrochemical and photoelectrochemical technologies and this work describes the fundamentals, main cases studied in the literature related to actual industrial waste treatment and tries to help in the elucidation of the range of applicability of each technology.
\end{abstract}

Key words: Advanced oxidation processes, industrial wastewaters, surface processes, bulk processes.

\section{Introduction}

At the earliest 70's Weber wrote a book entitled Physicochemical Processes [1]. In this book a special emphasis was made on physical and chemical unit operations that could be used in wastewater treatment. At that time, he introduced a chapter entitled Chemical Oxidation in which he compiled the ultimate research studies of some chemical oxidants that could react in aqueous solution. He postulated that from a thermodynamic point of view, oxidations of organic compounds with oxidants such as $\mathrm{O}_{2}, \mathrm{O}_{3}, \mathrm{KMnO}_{4}$ and $\mathrm{ClO}_{2}$ are favorable, whereas rates vary drastically. According to this proposal, in conventional biological wastewater treatments the dissolved pollutants are transformed into new cells, which in the clarifier can be separated by gravity. However, the sludge handling and final disposal always has associated costs $[2,3]$.On the contrary, when using oxidation the final products are $\mathrm{CO}_{2}, \mathrm{H}_{2} \mathrm{O}$ and in some cases mineral acids e.g. $\mathrm{HCl}$. Thus, there is not sludge generation and this represents a tremendous advantage since there is not
Resumen. En la actualidad uno de los principales problemas medioambientales de nuestra sociedad es la generación de grandes cantidades de aguas residuales. Generalmente, estas aguas son tratadas empleando combinaciones de métodos físicos, químicos y biológicos lo que permite alcanzar elevados rendimientos. Sin embargo, algunas aguas residuales industriales presentan contaminantes recalcitrantes, difíciles de eliminar empleando los métodos de tratamiento mencionados anteriormente, por lo que es necesario recurrir a otras técnicas de tratamiento. En estos casos, el empleo de técnicas de oxidación avanzadas (TOA) representa una prometedora alternativa para alcanzar la eliminación del contaminante. Las técnicas TOA se basan en la generación del radical hidroxilo, que es un poderoso agente oxidante, para mineralizar eficazmente los contaminantes del agua. En este artículo de revisión, se presentan las técnicas electroquímicas empleadas para generar el radical hidroxilo, empleando para ello técnicas electroquímicas tanto directas como indirectas, dentro de los denominados procesos de oxidación electroquímica avanzados (POEA). Estos procesos incluyen, tecnologías electroquímica, sonoelectroquímica y fotoelectroquímica. En este trabajo se describen los fundamentos y se presentan los principales casos de estudio publicados, con el objetivo de profundizar en el conocimiento de esta tecnología para ampliar su rango de aplicación.

Palabras Clave: Procesos de oxidación avanzada, aguas residuales industriales, procesos superficiales, procesos en la película líquida.

a handling and final disposal cost and also the environmental impact is diminished $[4,5]$.

In 1989, Eckenfelder in his book Industrial Wastewater Pollution Control [6] highlighted the stringent that environmental regulations had become and the need of redefinition of conventional technologies for wastewater treatment with new technologies. Indeed, as new pollutants were present in wastewater, many wastewater facilities became obsolete.

Almost 20 years later, in 2005, Tchobanoglous et al., in their book Water treatment Principles and Design [7], dedicate a vast chapter on chemical oxidation and reduction. For the first time the Advanced Oxidation Processes (AOP) were detailed and described in a 30 pages subchapter. One of the most important postulates was the declaration about AOP are feasible for full-scale use to destroy organic compounds because they generate hydroxyl radicals at ambient temperature and atmospheric pressure. Although a detailed description of the types of AOPs was included, the Electrochemical Advanced Oxidation Processes was not mentioned. These methods were 
first described in books focused on electrochemistry and more particularly in environmental electrochemistry [8-12].

The Electrochemical Advanced Oxidation Processes (EAOP) are, consequently, a very new class of oxidation processes that have been under research and although the state of the art results are published in scientific journals, a summary of the recent advances is not available, therefore this review paper aims to compile the information in a single document that indicates the principles and trends in this area.

All the AOP rely on the hydroxyl radical formation. The hydroxyl radical $\left({ }^{\circ} \mathrm{OH}\right)$ is a highly reactive radical which can rapidly degrade recalcitrant organics such as aromatic, chlorinated and phenolic compounds. The hydroxyl radical has a high oxidation potential as shown in Table 1 and can be produced in ozone oxidation, Fenton oxidation and, as it is going to be described in this manuscript, various electrochemical oxidation systems. In addition, this radical can also be produced from water by irradiation of light or ultrasound. This radical readily reacts with pollutants in wastewater; however they could also react with radical's scavenger such as bicarbonate ion, causing a reduction in the efficiency of the process [13].

Electro-Fenton was the first technology which could be considered as an EAOP because of the production and active role of hydroxyl radical on the oxidation of organics [14]. This technology is based on the promotion of one or several of these processes:

- the electrochemical regeneration of iron (II) from iron (III) species on the cathodic surface,

- the cathodic formation of hydrogen peroxide from the reduction of oxygen and

These processes lead to the catalytic decomposition of hydrogen peroxide into hydroxyl radical.

In 2003, Marselli and co-workers [15] demonstrated that the production of hydroxyl radicals during conductive-diamond electrolysis of aqueous wastes was possible. This was a milestone for the electrochemical oxidation, because it demonstrated that anodic oxidation also belongs to the group of the EAOP. From that moment, many other technologies have appeared, including combination of electrochemical production of oxidants and sound or light irradiation decomposition technologies.

Table 1. Oxidizing potential for some oxidizing agents [13].

\begin{tabular}{lc}
\hline Oxidizing Agent & Oxidation Potential (V) \\
\hline Fluorine & 3.06 \\
Hydroxyl radical & 2.80 \\
Oxygen (atomic) & 2.42 \\
Ozone & 2.08 \\
Hypochlorite & 1.49 \\
Chlorine & 1.36 \\
Hydrogen peroxide & 1.78 \\
Chlorine dioxide & 1.27 \\
Oxygen (molecular) & 1.23 \\
\hline
\end{tabular}

In this review, we focus on the use of electrochemical methods to produce hydroxyl radicals using direct or indirect electrochemical oxidation technology, within the so-called Advanced Electrochemical Oxidation Processes (EAOP). These technologies include electrochemical, sonoelectrochemical and photoelectrochemical processes and involve surface and bulk oxidation processes. Their advantages and disadvantages are critically reviewed in this work, reviewing the main works in which the treatment of actual industrial wastewaters have been assessed.

\section{Electrochemical processes in wastewater treatment}

Over the last two decades, various applications of electrochemical technology have arisen in the field of environmental remediation. Treatment of liquid wastes coming from different types of industries (by electrocoagulation, electrolysis or electrodialysis) and electrokinetic soil remediation processes become the most significant.

From the scientific point of view, electrolysis and electrocoagulation have been the two most exciting research topics in this period with hundreds of very significant references [16-18]. Electrocoagulation has demonstrated to be a very interesting technology for removal of turbidity, decolorization of dyes and breakup of wastes consisting of emulsions. However, it is not a final treatment but a pretreatment and hence, it is particularly interesting for the coarse removal of pollution [19].

Opposite to electrocoagulation, electrolysis should not be used as a treatment for the coarse removal of pollution in industrial waste because the amount of energy required for the abatement depends directly on the concentration of pollution to be removed. Likewise, it cannot be proposed as an alternative to biological oxidation processes, because these latter processes are much cheaper (typically by one magnitude order) and just in case biological oxidation could not be applied electrolysis can take a chance in the treatment of industrial waste. Hence, its target is the treatment of effluents polluted with anthropogenic organic species, either toxic or refractory to biological treatments, and within a concentration range which should be inside 1,000-20,000 mg Chemical Oxygen Demand (COD) $\mathrm{dm}^{-3}$ for direct anodic oxidations [20] and which can be enlarge to smaller values if mediated oxidation processes are promoted (and hence mass transfer limitations are overcome). Use of diamond electrodes has become an outreaching fact in this technology. This type of electrodes favors the production of hydroxyl radicals and their use in the production of other strong oxidants or their use in the harsh oxidation of organic species. This explains the great efficiency obtained and the great relevance of the research results of electrolysis during these two decades. Electrolysis with diamond anodes (often called as conductive-diamond electrochemical oxidation, CDEO) exhibits three outstanding properties as compared with other advanced oxidation technologies and with electrolysis with other anodes [20]: 
- robustness, because results found in this latter years demonstrate that it can attain the complete mineralization of almost any type of organic without producing refractory final products

- efficiency, because when it is operated under the no diffusion control, current efficiencies are close to $100 \%$

- integration capability, because it can be easily coupled with other treatment technologies and it can be fed with green energy sources such as wind mills and photovoltaics panels.

However, in spite of the large number of studies carried out, there is still a lot of work to do before its commercial application and many aspects must be enhanced. Two are of particular interest:

- The specificity of diamond electrodes and the elucidation of the influence of the diamond layer characteristics on the efficiency of the oxidation [21, 22]

- The potential improvements that could be obtained by the combination of CDEO with other technologies such as the irradiation of ultrasound or UV-light. This is because in the later years light irradiation and/or ultrasound irradiation have shown to significantly improve the results of many AOPs, in particular avoiding the production of refractory organics during the oxidation of complex pollutants [23-25]. This is not a limitation of the robust CDEO technology, but just a clarification of how sono- and photo- CDEO can improve results of conventional CDEO is worth of investigation.

Anyway, besides electrolysis with diamond anodes many other electrolytic technologies should be reviewed and next sections will deal with this description.

\section{Electrochemical processes on the surface of the electrodes}

In the literature, the EAOP are commonly divided into two groups depending on the place where the predominant mechanisms that explain the overall oxidation develop: surface of the electrodes or bulk of the electrochemical cell.

The surface-controlled processes, usually known as Anodic Oxidation processes, are those which take place mainly on the nearness of surface of the electrode. This means that electrode plays a significant role on results and that electrolysis should be considered as heterogeneous processes. Among them, three categories could be distinguished according to the main mechanisms that explain the oxidation carried out:

- Direct electron-transfer processes

- Hydroxyl radical processes

- Heterogeneous photocatalytic processes

\section{Direct electron transfer processes \& hydroxyl radicals mediated anodic oxidation: two faces of the same coin}

The heterogeneous electrolysis is a well-known technology for the oxidation of organic pollutants contained in wastewaters. In the last years, many studies have been done with both synthetic and real wastewaters, being proved its effectiveness and robustness [20].

In the direct oxidation, pollutants contained in the bulk of the wastewater must reach the electrode surface and the oxidation reaction takes places once they are adsorbed onto this surface. Consequently, the nature of the electrode materials influences the selectivity and efficiency of the oxidation process and mass transfer becomes a very important process, more often than not, the bottleneck of the oxidation rate.

Table 2 shows some anodic materials that have been frequently assessed for the oxidation of organic compounds. They are classified into two groups corresponding to the behavior observed in wastewater electrolysis processes.

At this point, it is worth taking into account that in the 90s of the former century, it was found that electrode materials behave in two different ways when organic pollutants contained in wastewater were oxidized on them. Several anodes (marked into Class 1 in Table 2) produce a soft oxidation of the organics, with the formation of polymers and many refractory species as final products of the electrolytic process. Typically, when the electrolytic process happening on these electrodes was studied with voltammetric techniques it was found a low oxygen evolution overpotential (OEP). On the contrary, the oxidation conditions produced during the bulk electrolysis of organic wastes with other electrodes (Class 2) were very harsh and organics were easily mineralized (transformed into carbon dioxide), with no production of polymers and few or nil concentration of refractory species. As expected, voltammetric studies with these electrodes showed a very high OEP.

Many different explanations were given to this observation but the most convincing was given by the group of Comninellis [26]. They explained the different behavior in terms of the electrolytic oxidation of water to hydroxyl radicals and the interaction of these radicals with the surface of the electrode. It is important to take into account that bulk electrolysis is usually carried out at large cell potentials, clearly over OEP

Table 2. Classification of anodic materials based upon oxygen evolution [125].

\begin{tabular}{lcc}
\hline Material & Class & $\begin{array}{c}\text { Oxygen Evolution } \\
\text { Potential }\end{array}$ \\
\hline $\mathrm{RuO}_{2}$ & 1 & 1.47 \\
$\mathrm{IrO}_{2}$ & 1 & 1.52 \\
$\mathrm{Pt}$ & 1 & 1.60 \\
$\mathrm{Graphite}_{\mathrm{SnO}_{2}}$ & 1 & 1.70 \\
$\mathrm{PbO}_{2}$ & 2 & 1.90 \\
$\mathrm{Boron}$ Doped Diamond (BDD) & 2 & 1.90 \\
\hline
\end{tabular}


and in those conditions oxidation of water, with a first stage of formation of hydroxyl radicals can be expected, although the behavior of the radicals can be completely different. In Class 1 electrodes (also called active electrodes) hydroxyl radical interact with the electrode surface and oxidation of organics was done by a direct transfer of electrons from this electrode surface (chemical oxidation of the pollutant by one of the species contained on the anode surface) and not by the action of hydroxyl radicals. As a consequence, in some cases the oxidation of the electrode results in electrode burning (e.g. graphite) and very low efficiencies are obtained. In other cases, it results in the formation of oxides (e.g. platinum, iridium dioxide electrodes), which attack chemically the organic pollutant with very different results in speciation and efficiency.

Opposite, in Class 2 electrodes (also called non-active), hydroxyl radicals do not interact with the anode surface but directly with organics in a reaction cage (or electrochemical reaction zone) very narrow in the nearness of the electrode surface (because average lifetime of hydroxyl radicals is very short). The very small width of this zone allows researchers to consider this process as an "almost" direct electrochemical process, although it is clearly a mediated electrochemical oxidation and some sort of confusion was made between purely anodic oxidation processes and these new types of processes. Characteristics of these processes are going to be further described in the next section. Opposite, in this section it is important to focus just on the processes happening on the electrode surface. At this point, mass transfer of pollutant from the bulk to the nearness of the electrode surface is the most important point because in this type of electrodes three stages should be completed: 1) pollutant transfer from the bulk solution to the electrode surface, 2) electrodic reaction (or mediated oxidation by hydroxyl radicals), and 3) oxidized product transfer from the electrode surface to the bulk. These stages are graphically represented in Figure 1.

At this point, if the pollutant does not arrive quickly enough to electrode surface, it is said that the reaction is mass-transfer controlled. The mass-transfer involves the transport of the pollutant by diffusion, convection and migration being convection the most important mechanisms in most electrochemical wastewater treatment technologies. Typically, the mass-transfer rate, can be modeled using Equation (1), where $r$ is the mass transfer rate $\left(\mathrm{g} \mathrm{s}^{-1}\right), \mathrm{k}_{\mathrm{m}}$ is the mass transfer coefficient $\left(\mathrm{m} \mathrm{s}^{-1}\right)$, $\mathrm{A}$ is the electrode surface $\left(\mathrm{m}^{2}\right)$, $\mathrm{P}^{\text {electr }}$ is the pollutant concentration in the electrode $\left(\mathrm{g} \mathrm{m}^{-3}\right)$ and $\mathrm{P}^{\text {bulk }}$ is the pollutant concentration in bulk solution $\left(\mathrm{g} \mathrm{m}^{-3}\right)$.

$$
\mathrm{r}=\mathrm{k}_{\mathrm{m}} \mathrm{A}\left(\left[\mathrm{P}^{\text {bulk }}\right]-\left[\mathrm{P}^{\text {electr }}\right]\right)
$$

Once the pollutant reaches the electrode surface the electrochemical reaction takes place. Two possibilities can be found:

- If there are mass transfer limitations, concentration of the pollutant at the anode surface is nil and rate of the electrolytic process can be simplified to Eq. 2.

$$
\mathrm{r}=\mathrm{k}_{\mathrm{m}} \mathrm{A}\left[\mathrm{P}^{\mathrm{bulk}}\right]
$$
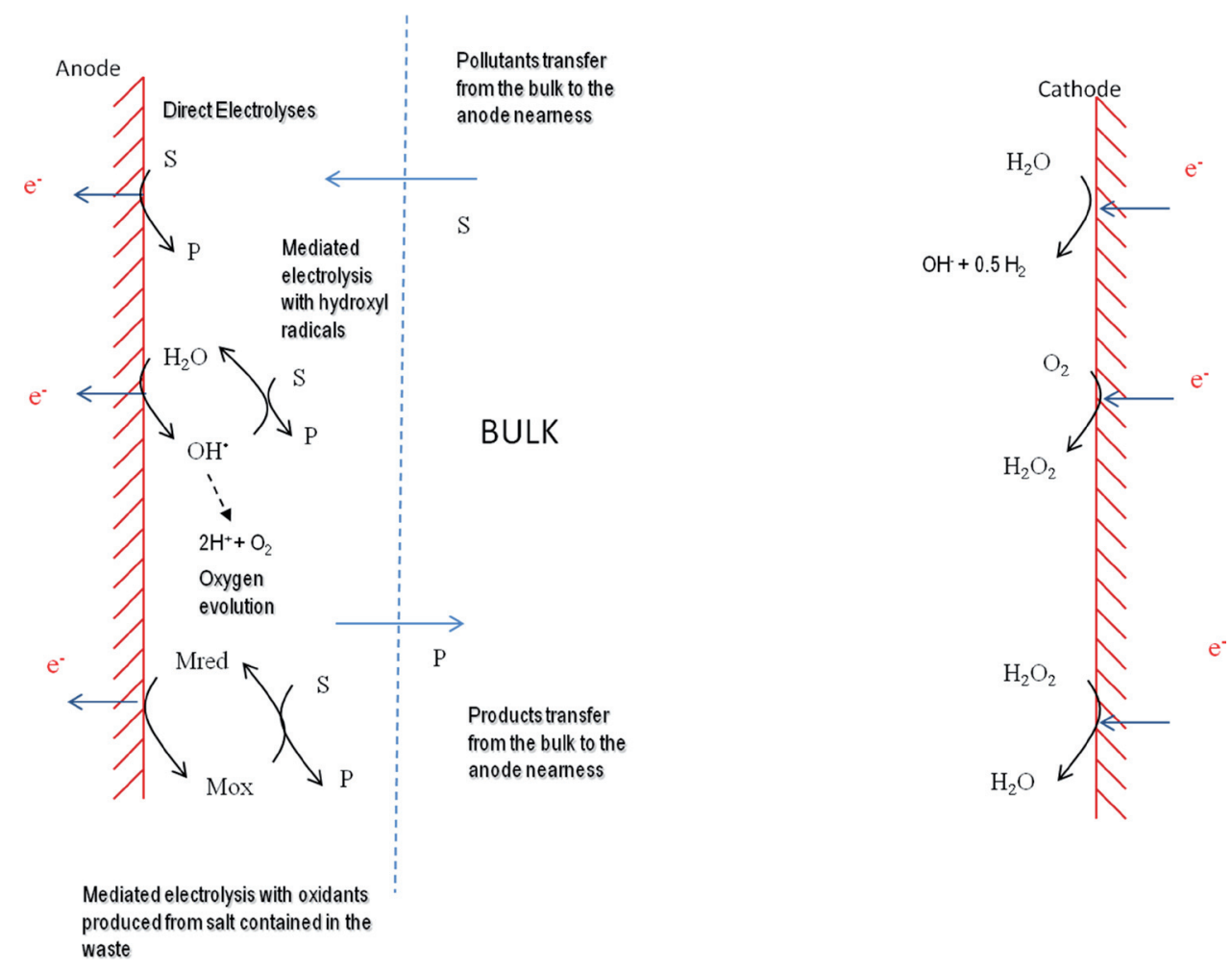

Figure 1. Mass transport controlled processes in anodic oxidation. 
- If there are not mass transfer limitations, the rate of the electrochemical oxidation of the compound is modelled in terms of the current density (j), electrode area (A), charge number of the electrode reaction (v) and Faraday constant (F) using Eq. 3.

$$
\mathrm{r}=\frac{\mathrm{jA}}{\mathrm{vF}}
$$

For a direct electro-oxidation process current density depends primarily on the overpotential $(\eta)$, through the well-known the Butler-Volmer equation in which dependence on temperature $(\mathrm{T})$ is also included. This equation can be simplified into the Tafel equation (Eq. 4) since the electrochemical oxidation of wastewater usually requires a large overpotential. In this Equation two parameters are considered, the exchange current density $\left(j_{0}\right)$ and the Tafel slope ( $\beta$ ).

$$
\mathrm{j}=\mathrm{j}_{0} \mathrm{e}^{\frac{\beta \mathrm{Fu \eta}}{\mathrm{RT}}}
$$

For an hydroxyl radical mediated oxidation (with hydroxyl radicals produced on the surface of the electrode surface) and due to the very short average lifetime of hydroxyl radicals and their very high reactivity, no macroscopic differences should be observed with respect to the kinetics of the direct electrochemical oxidation, because hydroxyl radical production rate is also described by the Tafel equation and the higher the overvoltage, the higher the production of hydroxyl radicals.

Anyway, in both cases mass transfer is controlling the maximum rate and only product distribution and efficiency can help to distinguish between the two limit behaviors: in this context the higher efficiency and effectiveness of the oxidation with hydroxyl radicals is the key to understand the better results with non-active electrodes.

Another interesting point is the formation of oxidants in the reaction media, which will be discussed afterwards in the next sections. In wastewater containing chloride, formation of chlorine and hypochlorite is well known with many types of anodes. However, oxidation of other anions is also possible and this mechanism seems to be promoted in the presence of hydroxyl radical meaning the effective formation of many interesting species such as peroxosulphates, peroxophosphates and peroxocarbonates in the nearness of the electrode surface or if these species are stable (meaning not extremely oxidizing reagents) in the bulk of the solution.

Table 3 shows some of the works in which pollutants treated under proper conditions and with anode materials exhibiting

Table 3. Direct Electrolysis of industrial wastewater using active electrodes.

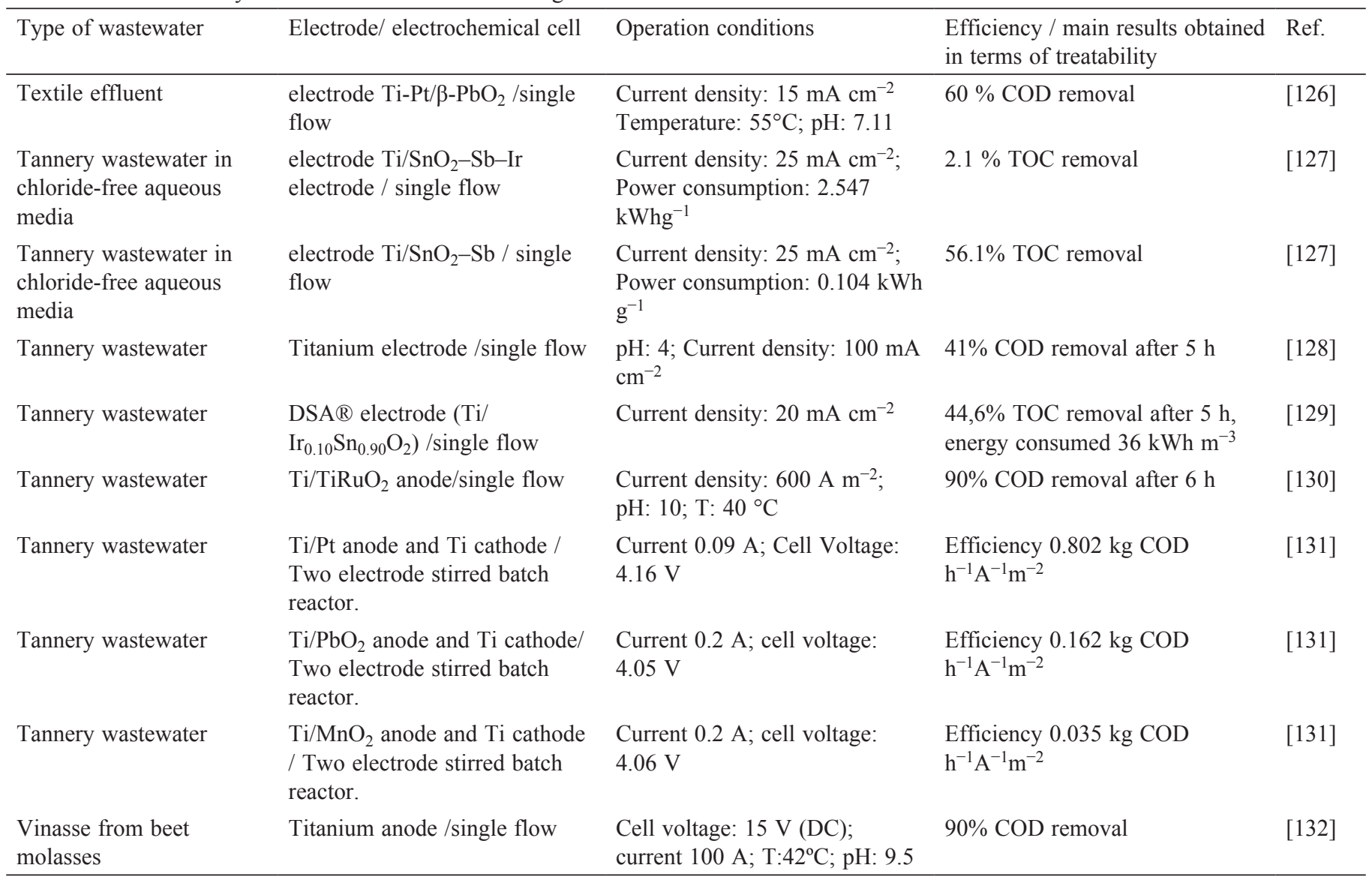


Table 3. Continues.

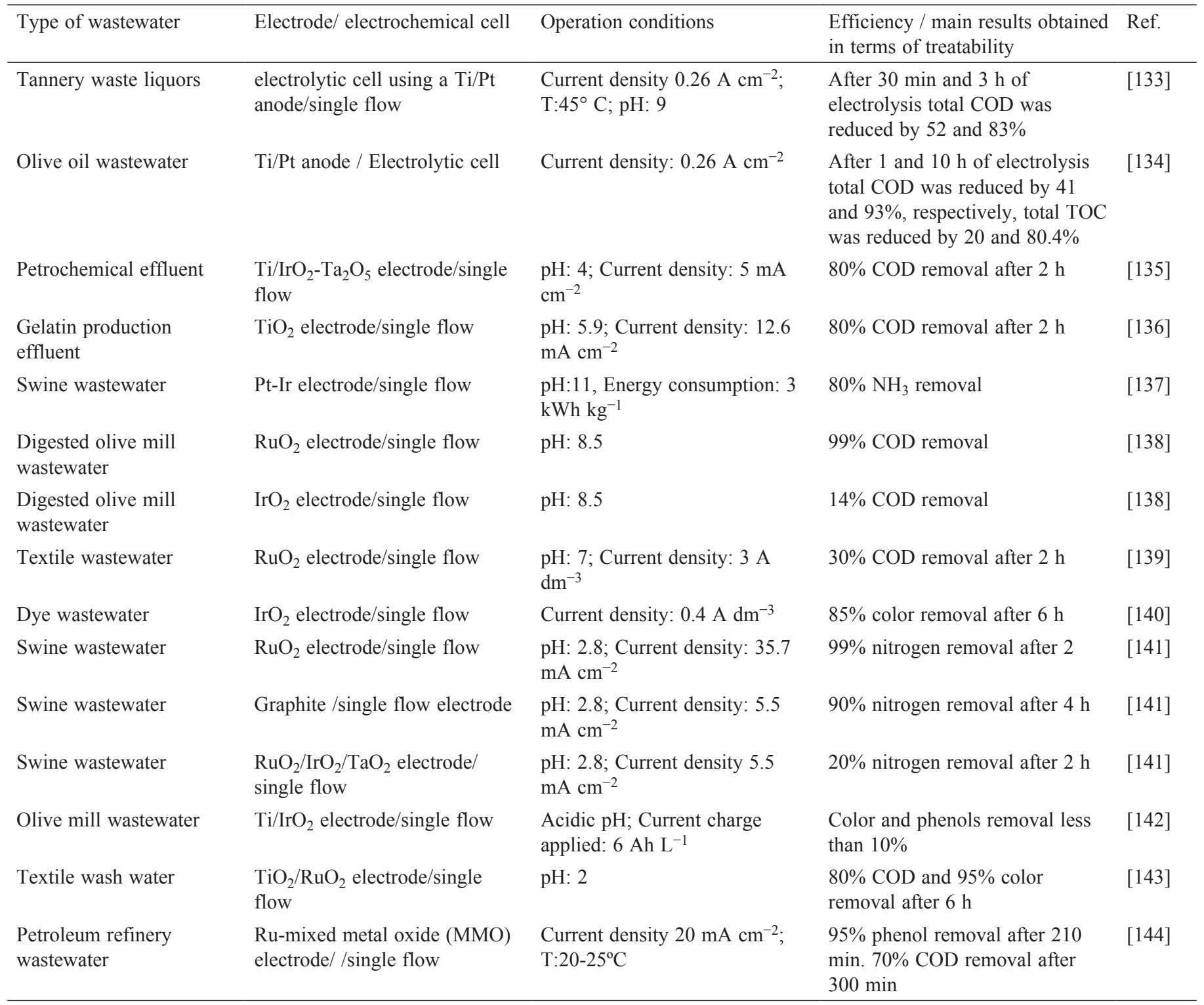

a clear Class 1 behavior (direct electron transfer is expected to be the main oxidation mechanisms) are assessed. As it can be observed efficiencies are low regardless of the operation conditions, in particular in terms of mineralization.

Table 4 shows some of the works reporting about pollutants treated under proper conditions and with different anode materials exhibiting Class 2 behavior (hydroxyl radical is expected to be the main oxidation mechanisms). As it can be observed, and opposite to the results shown in Table 4 efficiencies are very high in particular those related to mineralization.

\section{Heterogeneous photoelectrocatalysis}

Photoelectrochemical cells (PECs) were originally designed to undertake the photo-induced cleavage of water, generating oxygen at a titanium dioxide electrode, in an aqueous solution with the concomitant production of hydrogen gas, most often evolved at a platinum cathode [27].

All PECs rely on light for successful operation. Their use has since been extended for other applications, including the remediation of wastewater $[28,29]$. Several works were mainly based on the degradation of dyes, because in addition to their role as pollutants, they consist of large organic molecules in which synergistic effects of electrochemical and photochemical technologies can be more clearly identified. The results obtained indicated that the combination of photo and electrolysis technologies leads to a synergistic effect explained by heterogeneous (external bias contribute to a decrease in the electronhole pair recombination process and the UV-photons reaching the electrode surface form excited radicals) and homogenous (photoactivation of electrochemically generated reactive species) catalytic processes. 
Table 4. Direct Electrolysis of industrial wastewater using non-active electrodes.

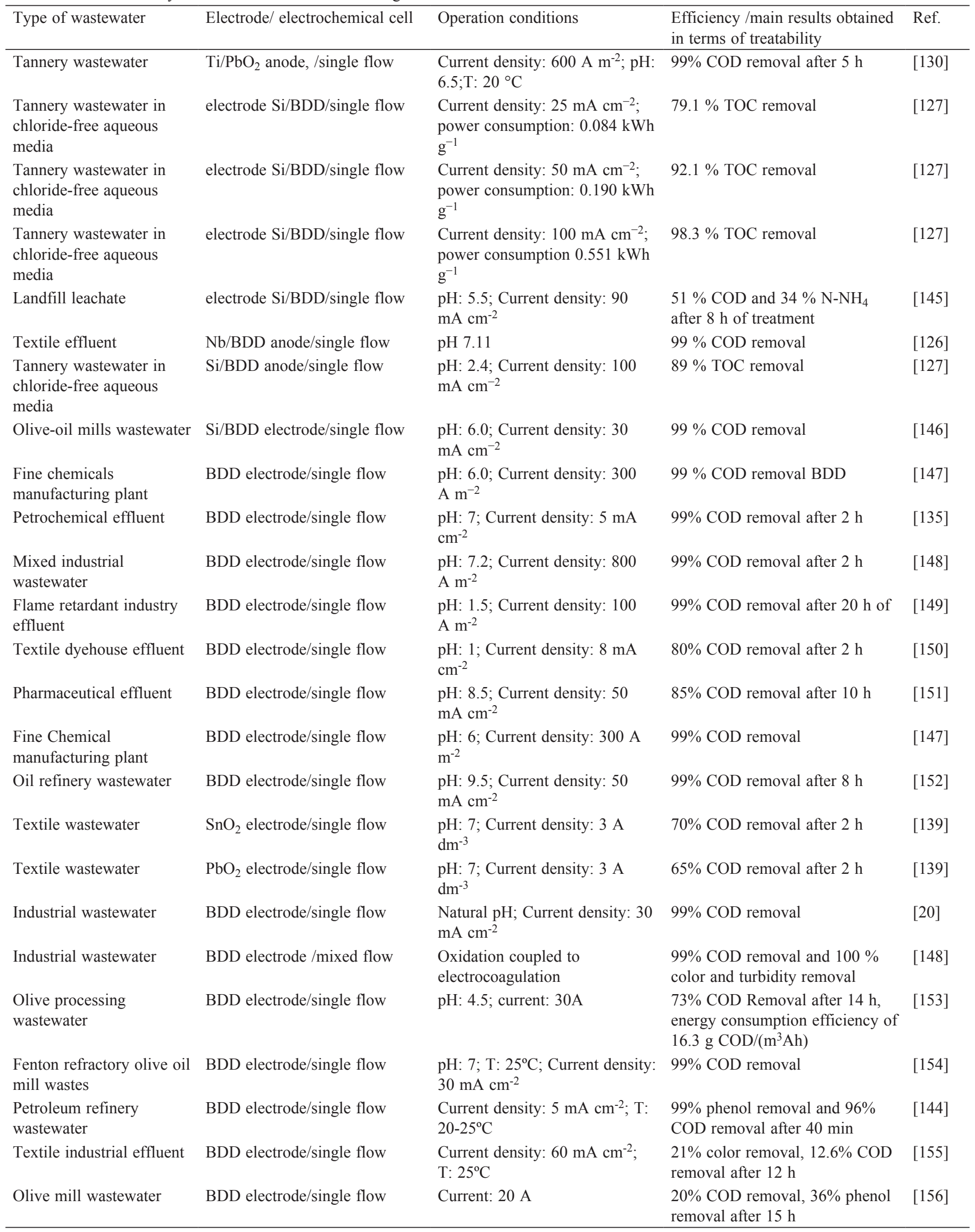


Recent reports have highlighted PEC cells that are capable of spontaneously degrading a wide variety of organic substrates ranging from biomass like polysaccharides, proteins, lignin, and cellulose to simple alcohols and sugars. Various other compounds were also successfully degraded with PECs including nitrogen-containing substances such as ammonia, urea, urine, and synthetic polymers like polyethylene glycol and poly(acrylamide). All these compounds were mineralized while also creating photocurrent [30-33].

Mechanisms of oxidation in heterogeneous photoelectrocatalysis were proposed by Pelegrini et al., (2000) in one of the first pioneering [34] and they connect with the two first types of electrochemical surface-controlled processes. Thus,

- in the presence of photons, the external bias can contribute to a decrease in the electron-hole pair recombination process. The reactions that are expected to take place are represented in eqs. 5 and 6 . Where $\mathrm{h}^{+}{ }_{\mathrm{VB}}$ represents the photogenerated holes and $\mathrm{e}_{\mathrm{CB}}^{-}$the electrons released.

$$
\begin{gathered}
\mathrm{TiO}_{2}+\mathrm{hv} \rightarrow \mathrm{TiO}_{2}+e_{\mathrm{CB}}^{-}+\mathrm{h}_{\mathrm{VB}}^{+} \\
\mathrm{h}_{\mathrm{VB}}^{+}+\mathrm{H}_{2} \mathrm{O} \rightarrow{ }^{\circ} \mathrm{OH}+\mathrm{H}^{+}
\end{gathered}
$$

- photons reach the surface of the electrode during the electrochemical step, generating excited radicals according to Eq. 7, which can enhance the treatment efficiency

$$
\mathrm{MO}_{x}(\mathrm{OH})^{\bullet} \stackrel{h v}{\longrightarrow} \mathrm{MO}_{x}\left(\mathrm{OH}^{\bullet}\right)
$$

In literature, pioneering reports were published at the turn of the century and during the last decade. These works were focused on the development of heterogenous photo-electrocatalysts on the surface of the anodes. These photo-electrocatalysts were based on Mixed Metal Oxides (MMO) anodes. Most of these $\mathrm{MMO}$ catalysts were based on the use of titanium dioxide and ruthenium. A 30/70 \% composition ratio $\left(\mathrm{Ti} / \mathrm{Ru}_{0.3} \mathrm{Ti}_{0.7} \mathrm{O}_{2}\right)$ has been reported in literature to remove complex pollutants such as dyes [35-40] and humid acids [41]. In several works, other metal oxides such as tin dioxide were added to the conventional MMO electrodes with ruthenium and titanium oxides
[34] and in other works the more energetic lead dioxide, instead of ruthenium oxide, was used as additive in the conventional MMO electrodes [42]. Other electrodes reported in literature were based on titanium-supported $\left(\mathrm{Ti} / \mathrm{TiO}_{2}\right.$ thin film) photoelectrodes $[43,44]$ and on the conductive diamond electrode [45]. In these works, synergistic effects due to the combination of the photo irradiation and the electrochemical process were observed on results of the treatment, yielding higher removal percentages than expected based on the separate contribution of both oxidation technologies.

Table 5 shows some of the pollutants treated with different anode materials in which heterogeneous photochemical reactions are expected to be responsible for the main oxidation.

\section{Bulk processes in EAOP}

The bulk oxidation comprises indirect oxidation processes that require the electrochemical generation of a mediator which can then react in the bulk solution. This mediator can be generated anodically (or cathodically), and it is responsible for the oxidation of pollutants in wastewater. The most common electrochemical indirect agents are chlorine and hydrogen peroxide. However, almost any salt contained in a waste can produce oxidants which act in the bulk and because of this, the role of chlorine [46-49], sulphates [50-52], phosphates [53, 54] and many other types of salt anions on the electrochemical destruction of organics have been extensively studied in the literature.

It is important to bear in mind that production and action of oxidants is a set of processes occurring in all electrolysis and that it could be promoted with the addition of reagents (chloride, oxygen) that promotes the formation of oxidants. There are no pure bulk electrochemical processes but electrochemical processes in which contribution of bulk processes is more important in the oxidation of organics than the contribution of surface processes. This can be clearly observed in Figure 2 in which mechanisms for the oxidation of organic pollutants in wastewater treatment are clearly summarized. Production of oxidant species during electrochemical treatment of wastewater has encouraged many research groups to study the synthesis of particulate oxidants and to isolate them as valuable products.

One very important point to be considered in bulk process-

\begin{tabular}{|c|c|c|c|c|}
\hline Type of wastewater & Electrode/ electrochemical cell & Operation conditions & $\begin{array}{l}\text { Efficiency /main results obtained } \\
\text { in terms of treatability }\end{array}$ & Ref. \\
\hline $\begin{array}{l}\text { Pharmaceutical } \\
\text { wastewater }\end{array}$ & $\mathrm{TiO}_{2}$ electrode/special desing & $\begin{array}{l}\mathrm{pH}: 7 \text {, Current applied: } 6 \mathrm{~A} \text {; } \\
\text { irradiated with a } 150 \mathrm{~W} \text { xenon } \\
\text { lamp. }\end{array}$ & $55 \%$ TOC removal after $2 \mathrm{~h}$ & [157] \\
\hline Dye wastewater & $\mathrm{TiO}_{2}$ electrode /special desing & $\begin{array}{l}\text { Current density: } 1 \mathrm{~mA} \mathrm{~cm}^{-2} \text {; } \\
\text { irradiation during } 1 \mathrm{~h} \text { with a } \\
\mathrm{UV} \text { lamp }\left(21 \mathrm{~W} \mathrm{~cm}^{-2}\right)\end{array}$ & $\begin{array}{l}25 \% \text { TOC removal with a } \\
\text { operated at }\end{array}$ & [158] \\
\hline
\end{tabular}
es is that oxidants produced in the electrochemical treatments

Table 5. Treatment of industrial wastewater using heterogeneous photo-electrocatalysis technologies. 

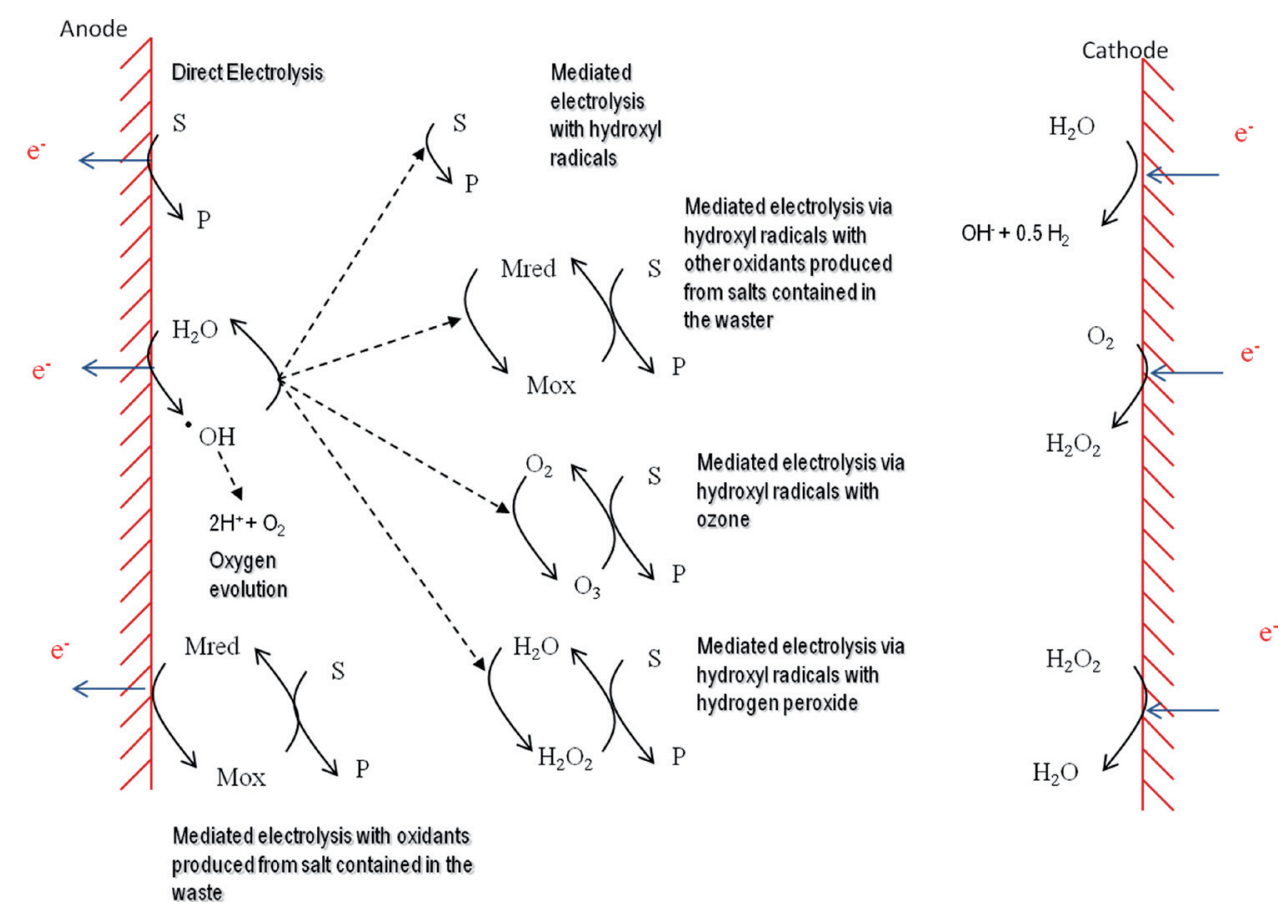

Figure 2. Mechanisms of direct and mediated oxidation of organics.

can be activated by different ways looking for harsher oxidation conditions. For this reason, four points are of particular interest regarding bulk processes

- Production of oxidants

- Chemical activation of oxidants

- Activation of oxidants by light irradiation

- Activation of oxidants by ultrasound irradiation.

\section{Production of oxidants in EAOP}

Although many species can play an important role in bulk oxidation, this section is going to be focused only on the most relevant including chlorine, hydrogen peroxide, peroxocompounds and ferrates.

Regarding chlorine, it is easily produced in wastewater containing chloride and because this anion is contained in many industrial wastewater streams, it uses to play a very important role in the electrolysis of many actual wastes. Chlorine is produced on the surface of the anode (Eq. 8) and it suffers many significant speciation reactions in the bulk, which are strongly influenced by $\mathrm{pH}$, including disproportionation (Eq. 9) to hypochlorous acid, and hydrolysis to hypochlorite (Eq. 10).

$$
\begin{gathered}
2 \mathrm{Cl}^{-} \leftrightarrows \mathrm{Cl}_{2}+2 \mathrm{e}^{-} \\
\mathrm{Cl}_{2}+\mathrm{H}_{2} \mathrm{O} \leftrightarrows \mathrm{HOCl}+\mathrm{H}^{+}+\mathrm{Cl}^{-} \\
\mathrm{HOCl} \leftrightarrows \mathrm{H}^{+}+\mathrm{OCl}^{-}
\end{gathered}
$$

These different species explain the large influence of $\mathrm{pH}$ on the results of the electrolysis of industrials wastes. In ad- dition, although chlorine, hypochloric acid and hypochlorite are powerful oxidants, three drawbacks are associated to their use:

- formation of organochlorinated species by addition reactions of chlorine with different functional groups of organic matter, being these new species typically more hazardous than the parent pollutants. Obviously, their generation advices against the use of the electrochemical technology.

- Production of chlorates which may occur either electrochemically (Eq. 11) or chemically (Eqs. 12 and 13). In the latter case, its production is promoted by the ageing of the hypochlorite and it is a well-known phenomenon typically taking place in the storage of hypochlorite. Chlorate is not a good oxidant for organic matter under the conditions used in electrolysis (very slow kinetically at room temperature).

$$
\begin{gathered}
6 \mathrm{HOCl}+3 \mathrm{H}_{2} \mathrm{O} \rightarrow 2 \mathrm{ClO}_{3}^{-}+ \\
4 \mathrm{Cl}^{-}+12 \mathrm{H}^{+}+1.5 \mathrm{O}_{2}+6 \mathrm{e}^{-} \\
3 \mathrm{Cl}_{2}(\mathrm{~g})+6 \mathrm{NaOH}(\mathrm{aq}) \rightarrow \mathrm{NaClO}_{3}+5 \mathrm{NaCl}+3 \mathrm{H}_{2} \mathrm{O} \\
3 \mathrm{ClO}^{-} \rightarrow \mathrm{ClO}_{3}^{-}+2 \mathrm{Cl}^{-}
\end{gathered}
$$

- For some electrodes such as the BDD, perchlorate is also known to be formed during the electrolysis, because of the action of hydroxyl radicals $[55,56]$ summarized in Eqs. 14-17. The hazardousness of perchlorate prevents the use of this electrode material in the treatment of industrial wastes which contain high loads of chlorides. 


$$
\begin{gathered}
\mathrm{Cl}^{-}+\cdot \mathrm{OH} \leftrightarrows \mathrm{ClO}^{-}+\mathrm{H}^{+}+\mathrm{e}^{-} \\
\mathrm{ClO}^{-}+\cdot \mathrm{OH} \leftrightarrows \mathrm{ClO}_{2}^{-}+\mathrm{H}^{+}+\mathrm{e}^{-} \\
\mathrm{ClO}_{2}^{-}+\cdot \mathrm{OH} \leftrightarrows \mathrm{ClO}_{3}^{-}+\mathrm{H}^{+}+\mathrm{e}^{-} \\
\mathrm{ClO}_{3}^{-}+\cdot \mathrm{OH} \leftrightarrows \mathrm{ClO}_{4}^{-}+\mathrm{H}^{+}+\mathrm{e}^{-}
\end{gathered}
$$

Some papers in which the effect of chlorine has been found to be very relevant for the treatment of actual wastes are summarized in Table 6.

In addition to chlorides, many other salts are present typically in the composition of industrial wastewater. The most significant group of oxidants which can be formed from these salts is the peroxo group, composed of oxidants that are characterized by the presence of oxygen bonds in the molecule (-O-O-). The anodic oxidation production of oxidants such as $\mathrm{C}_{2} \mathrm{O}_{8}^{2-}, \mathrm{S}_{2} \mathrm{O}_{8}^{2-}$, and $\mathrm{P}_{2} \mathrm{O}_{8}^{4-}$ has been reported on $\mathrm{PbO}_{2}$ and $\mathrm{BDD}$ anodes. The reactions that take place are [57-59]:

$$
\begin{aligned}
& 2 \mathrm{CO}_{3}^{2-} \leftrightarrows \mathrm{C}_{2} \mathrm{O}_{8}^{2-}+2 \mathrm{e}^{-} \\
& 2 \mathrm{SO}_{4}^{2-} \leftrightarrows \mathrm{S}_{2} \mathrm{O}_{8}^{2-}+2 \mathrm{e}^{-} \\
& 2 \mathrm{PO}_{4}^{3-} \leftrightarrows \mathrm{P}_{2} \mathrm{O}_{8}^{4-}+2 \mathrm{e}^{-}
\end{aligned}
$$

As for chlorine, mediated oxidation with peroxosalts is strongly related to $\mathrm{pH}$, because of the different speciation of these oxidants with the $\mathrm{pH}$. Two subgroups are of particular relevance because of the significant presence of anions in typical industrial wastes: peroxosulfates and peroxophosphates. Regarding peroxosulfates $[60,61]$, these species are formed from the oxidation of sulfates. There are two different species: peroxomonosulfuric and peroxodisulfuric acids. Both acids have a very high reduction potential (1.81 and 2.08 respectively) and their production can be associated to direct electron transfer processes (Eq. 21) or to hydroxyl radicals mediated oxidation (Eq. 22 to 24 )

$$
\begin{gathered}
2 \mathrm{H}_{2} \mathrm{SO}_{4} \leftrightarrows \mathrm{H}_{2} \mathrm{~S}_{2} \mathrm{O}_{8}+2 \mathrm{e}^{-}+2 \mathrm{H}^{+} \\
\mathrm{HSO}_{4}^{-}+\cdot \mathrm{OH} \rightarrow \mathrm{SO}_{4}^{-}+\mathrm{H}_{2} \mathrm{O} \\
\mathrm{SO}_{4}^{2-}+\cdot \mathrm{OH} \rightarrow \mathrm{SO}_{4}^{-}+\mathrm{OH}^{-} \\
\mathrm{SO}_{4}^{-}+\mathrm{SO}_{4}^{-} \rightarrow \mathrm{S}_{2} \mathrm{O}_{8}^{2-}
\end{gathered}
$$

Its effect is known to be smaller at high temperature because it is well known that the peroxosulfuric acids decompose with temperature to yield sulfuric acid and hydrogen peroxide eq. 25-27.

$$
\begin{gathered}
\mathrm{S}_{2} \mathrm{O}_{8}^{2-}+\mathrm{H}_{2} \mathrm{O} \rightarrow 2 \mathrm{SO}_{4}^{2-}+2 \mathrm{H}^{+}+1 / 2 \mathrm{O}_{2} \\
\mathrm{~S}_{2} \mathrm{O}_{8}^{2-}+\mathrm{H}_{2} \mathrm{O} \rightarrow \mathrm{SO}_{5}^{2-}+\mathrm{SO}_{4}^{2-}+2 \mathrm{H}^{+} \\
\mathrm{SO}_{5}^{2-}+\mathrm{H}_{2} \mathrm{O} \rightarrow \mathrm{H}_{2} \mathrm{O}_{2}+\mathrm{SO}_{4}^{2-}
\end{gathered}
$$

The other important subgroup is peroxophosphates. The chemistry of the peroxophosphates is similar to that of persulfates and two main species can also be found: peroxomonophoshate and peroxodiphosphate. Peroxomonophosphate is stable at acid $\mathrm{pH}$ whereas peroxodiphosphate is more stable at alkaline $\mathrm{pH}$. Peroxodiphosphates are also known be produced by direct electron transfer (Eq. 1) or by the action of hydroxyl radicals as indicated in eqs. 28 to 31 .

$$
\begin{gathered}
2 \mathrm{PO}_{4}^{3-} \leftrightarrows \mathrm{P}_{2} \mathrm{O}_{8}^{4-}+2 \mathrm{e}^{-} \\
\mathrm{H}_{2} \mathrm{PO}_{4}^{-} \rightarrow\left(\mathrm{H}_{2} \mathrm{PO}_{4}\right)^{\bullet}+\mathrm{e}^{-} \\
\mathrm{H}_{2} \mathrm{PO}_{4}^{-}+\mathrm{OH}^{\cdot} \rightarrow\left(\mathrm{H}_{2} \mathrm{PO}_{4}\right)^{\bullet}+\mathrm{OH}^{-} \\
\left(\mathrm{H}_{2} \mathrm{PO}_{4}\right)^{\bullet}+\cdot \mathrm{OH} \rightarrow \mathrm{H}_{3} \mathrm{PO}_{5}
\end{gathered}
$$

Temperatures higher than $25^{\circ} \mathrm{C}$ lead to low conversions and efficiencies in the production of peroxophosphates. This could be explained by the thermal decomposition of peroxodiphosphate to give pyrophosphate and oxygen (eq. 32).

$$
\mathrm{P}_{2} \mathrm{O}_{8}^{4-} \leftrightarrows \mathrm{P}_{2} \mathrm{O}_{7}^{4-}+1 / 2 \mathrm{O}_{2}
$$

Production of oxidants from salt cations is much more difficult. One of the few examples that are reported in the literature is the production of ferrates which could become important when iron species are present in wastewater especially because its addition in other treatment processes. Ferrates, $\mathrm{FeO}_{4}{ }^{-2}$, are characterized by an unusual oxidation state, +6 , being a powerful oxidizing agent. Moreover, during the oxidation process, ferrate (VI) ions are reduced to Fe (III) or to ferric hydroxide, making them suitable to be used in a wide range of applications [62-71] and because of that its effect should only be important working at extremely high $\mathrm{pHs}$.

Some papers in which the effect of electrolyte (different of chloride) has been found to be very relevant for the treatment of actual wastes are summarized in Table 7 .

The third type of oxidants with relevance in bulk electrolysis is hydrogen peroxide, which is typically produced on the cathode and by decomposition of other oxidants in the bulk. The electrolytic production of $\mathrm{H}_{2} \mathrm{O}_{2}$ requires the dosing of oxygen gas into the electrochemical cell and a proper electrode surface. Several materials have been tested such as reticulated vitreous carbon, carbon cloth, graphite, oxygen diffusion cathodes and recently boron doped diamond [72-75]. In acidic media the reaction that takes place is shown in Eq. 33.

$$
\mathrm{O}_{2}(\mathrm{~g})+2 \mathrm{H}^{+}+2 \mathrm{e}^{-} \leftrightarrows \mathrm{H}_{2} \mathrm{O}_{2}
$$

As indicated by Bard [76], the hydrogen peroxide will form the hydroxyl radical at the cathode (Eq. 34). In aqueous solution a chain reaction then occurs between the hydroxyl radical and an organic compound $\mathrm{R}$ [77], summarized in eqs. 35-37. Therefore, the main advantage of hydrogen peroxide is the production of hydroxyl radical, which will react with the organic pollutants present in the wastewater. 
Table 6. Treatment of industrial wastewater with high content of chlorides by electrolysis.

\begin{tabular}{|c|c|c|c|c|}
\hline Type of wastewater & Electrode/ electrochemical cell & Operation conditions & $\begin{array}{l}\text { Efficiency /main results obtained } \\
\text { in terms of treatability }\end{array}$ & Ref. \\
\hline $\begin{array}{l}\text { Synthetic tannery } \\
\text { wastewater }\end{array}$ & $\mathrm{Ti} / \mathrm{IrSnO}_{2}$ anodes & $\begin{array}{l}\mathrm{pH}: 3.3 \text {; current density } 20 \mathrm{~mA} \\
\mathrm{~cm}^{-2} \text {; electrolyte concentration } \\
500 \mathrm{mmol} \mathrm{L}^{-1} \mathrm{NaCl}\end{array}$ & $100 \%$ TOC removal & [129] \\
\hline $\begin{array}{l}\text { Saline industrial } \\
\text { wastewaters }\end{array}$ & BDD anodes & $\begin{array}{l}\mathrm{pH} \text { Neutral-alkaline; current } \\
\text { density: } 150 \mathrm{~A} \mathrm{~m}^{-2} \text {; minimum } \\
\text { concentration of NaCl: } 1650 \\
\mathrm{mg} \mathrm{L}^{-1}\end{array}$ & $95 \%$ TOC removal & {$[160]$} \\
\hline $\begin{array}{l}\text { Low salinity reverse } \\
\text { osmosis concentrates }\end{array}$ & BDD anodes & $\begin{array}{l}\mathrm{pH}: 8 \text {; current density: } 10 \mathrm{~mA} \\
\mathrm{~cm}^{-2} \text {; minimum concentration of } \\
\mathrm{NaCl}: 600 \mathrm{mg} \mathrm{L}^{-1}\end{array}$ & $99 \%$ TOC removal using with a & {$[161]$} \\
\hline $\begin{array}{l}\text { Low salinity reverse } \\
\text { osmosis concentrates }\end{array}$ & $\mathrm{RuO}_{2}$ anodes & $\begin{array}{l}\text { Current density: } 30 \mathrm{~mA} \mathrm{~cm}^{-} \\
\text {2; minimum concentration of } \\
\mathrm{NaCl}: 600 \mathrm{mg} \mathrm{L}^{-1}\end{array}$ & $30 \%$ TOC removal & {$[161]$} \\
\hline Textile wastewater & Ti/Pt-Ir electrode & $\begin{array}{l}\mathrm{pH}: 11.5 \text {; current density: } 260 \\
\text { A m-2: concentration of } \mathrm{NaCl} \text { : } \\
2500 \mathrm{mg} \mathrm{L}^{-1}\end{array}$ & $99 \%$ color removal & {$[163]$} \\
\hline Textile wastewaters & Ti/Pt-Ir electrode & $\begin{array}{l}\text { current density: } 200 \mathrm{~A} \mathrm{~m}^{-2} \text {; } \\
\text { concentration of } \mathrm{NaCl}: 0.1 \mathrm{~mol} \\
\mathrm{~L}^{-1}\end{array}$ & $90 \%$ dye COD removal & {$[164]$} \\
\hline Tannery wastewaters & Ti/Pt-Ir electrode & $\begin{array}{l}\text { current density: } 400 \mathrm{~A} \mathrm{~m}^{-2} \text {; } \\
\text { concentration of } \mathrm{NaCl} 0.1 \mathrm{~mol} \\
\mathrm{~L}^{-1}\end{array}$ & $50 \%$ tannery COD removal & {$[164]$} \\
\hline Simulated dye wastewater & Pt anode and steel cathode & $0.2 \mathrm{M} \mathrm{NH}_{4} \mathrm{Cl}$ & $70 \%$ COD removal & {$[165]$} \\
\hline Olive mill wastewater & $\mathrm{Ti} / \mathrm{IrO}_{2}$ electrode & $\begin{array}{l}\text { Acidic } \mathrm{pH} \text {; Current charge } \\
\text { applied: } 6 \mathrm{Ah} / \mathrm{L} \text {, Concentration } \\
\text { of } \mathrm{NaCl}: 15 \mathrm{mM} ; \mathrm{T}: 80^{\circ} \mathrm{C}\end{array}$ & $\begin{array}{l}30 \% \text { COD removal and complete } \\
\text { color and phenols removal. }\end{array}$ & {$[142]$} \\
\hline Landfill leachate & BDD anodes & $\begin{array}{l}\mathrm{pH}: 2.5 \text {; current density: } \\
900 \mathrm{~A} \mathrm{~m}^{-2} \text {, Concentration of } \\
\text { chloride: } 1350 \mathrm{mg} / \mathrm{L}\end{array}$ & $90 \%$ COD and NH4 removal & {$[168]$} \\
\hline Landfill leachate & $\mathrm{Ti}_{\mathrm{x}} \mathrm{Ru}_{\mathrm{y}} \mathrm{Sn}_{\mathrm{z}} \mathrm{O}$ anodes & $\begin{array}{l}\mathrm{pH} 8.2 ; \mathrm{T}: 25^{\circ} \mathrm{C} \text {, current } 2 \mathrm{~A}: \\
\text { concentration of chlorides: } 1800 \\
\mathrm{mg} \mathrm{L}^{-1}\end{array}$ & $\begin{array}{l}35 \% \mathrm{COD}, 65 \% \text { ammonium and } \\
52 \% \text { color removal after } 8 \mathrm{~h}\end{array}$ & {$[169]$} \\
\hline Landfill leachate & $\mathrm{PbO}_{2}$ anodes & $\begin{array}{l}\mathrm{pH} 8.2 ; \mathrm{T}: 25^{\circ} \mathrm{C} \text {, current: } 2 \mathrm{~A} \text { : } \\
\text { Concentration of chloride: } 1800 \\
\mathrm{mg} / \mathrm{L}\end{array}$ & $\begin{array}{l}90 \% \mathrm{COD}, 100 \% \text { ammonium } \\
\text { and } 100 \% \text { color removal after } \\
8 \mathrm{~h}\end{array}$ & [169] \\
\hline Landfill leachate & $\mathrm{Ti}_{\mathrm{x}} \mathrm{Ru}_{\mathrm{y}} \mathrm{Sn}_{\mathrm{z}} \mathrm{O}$ anodes & $\begin{array}{l}\mathrm{pH} 8.2, \mathrm{~T}: 25^{\circ} \mathrm{C} \text {, current: } 2 \mathrm{~A} \text {; } \\
\text { concentration of chloride: } 1800 \\
\mathrm{mg} \mathrm{L}^{-1}\end{array}$ & $\begin{array}{l}100 \% \mathrm{COD}, 100 \% \text { ammonium } \\
\text { and } 100 \% \text { color removal after } \\
8 \mathrm{~h}\end{array}$ & [169] \\
\hline $\begin{array}{l}\text { Ink manufacturing } \\
\text { wastewater }\end{array}$ & BDD electrode & $\begin{array}{l}\text { Neutral } \mathrm{pH} \text {; current density: } \\
30 \mathrm{~mA} \mathrm{~cm} \text {; } \text { Concentration of } \\
\mathrm{NaCl}: 0.1 \mathrm{M}\end{array}$ & $90 \%$ COD removal & {$[53]$} \\
\hline
\end{tabular}


Table 6. Continues.

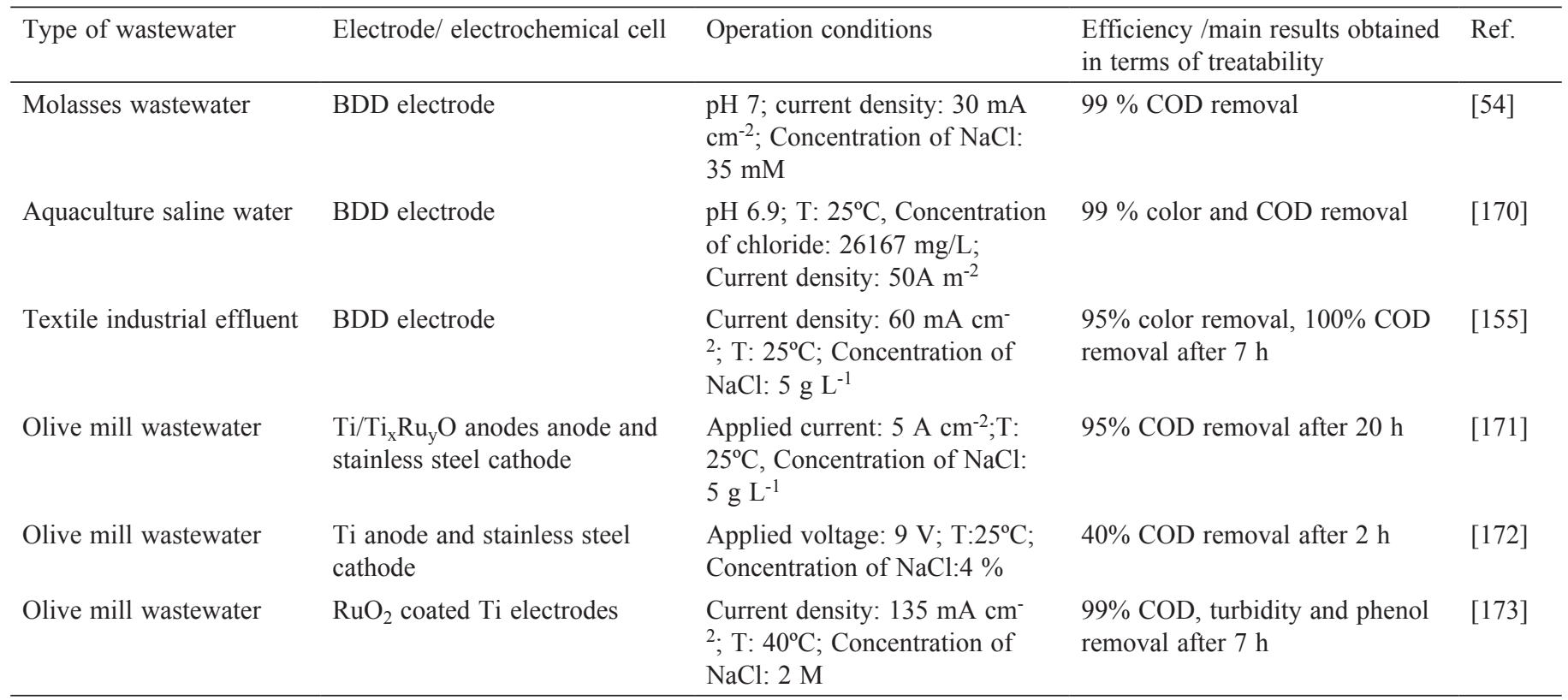

Table 7. Treatment of industrial wastewater with high content of salts excluding chlorides by electrolysis.

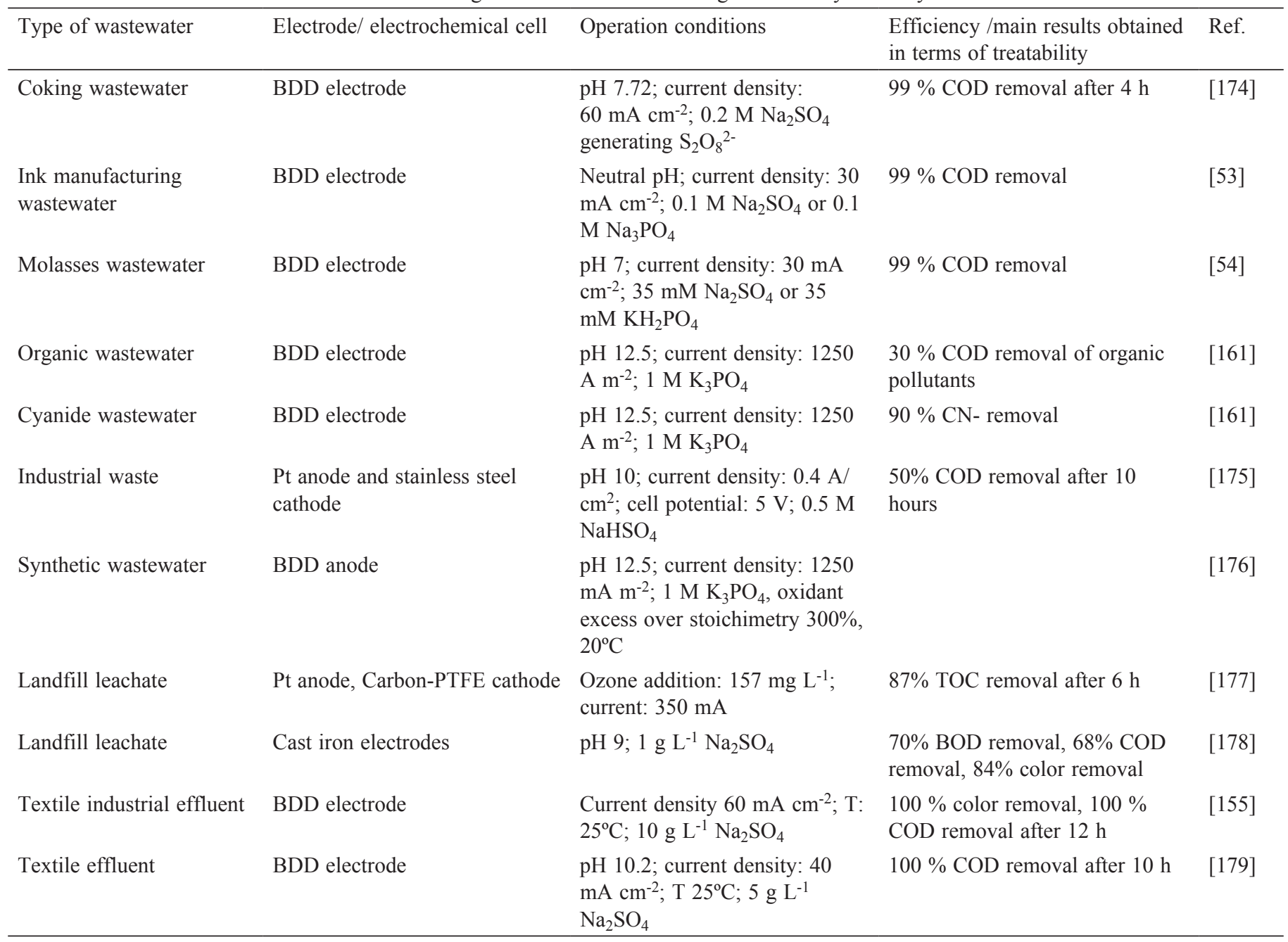




$$
\begin{gathered}
\mathrm{H}_{2} \mathrm{O}_{2}+\mathrm{e}^{-}+\mathrm{H}^{+} \leftrightarrows \mathrm{H}_{2} \mathrm{O}+{ }^{\bullet} \mathrm{OH} \\
\mathrm{RH}+{ }^{\bullet} \mathrm{OH} \leftrightarrows \mathrm{R}^{\bullet}+\mathrm{H}_{2} \mathrm{O} \\
\mathrm{R}^{\bullet}+\mathrm{O}_{2} \leftrightarrows \mathrm{ROO} \bullet \\
\mathrm{ROO}^{\bullet}+\mathrm{RH} \leftrightarrows \mathrm{ROOH}+\mathrm{R}^{\bullet}
\end{gathered}
$$

Some recent works focused on the use of hydrogen peroxide to remove pollutants contained in industrial wastes are summarized in Table 8.

\section{Chemical activation of oxidants produced in electrochemical processes}

As explained before for the chlorine/ hypochlorite/hypochloric acid, changes in the $\mathrm{pH}$ can modify the oxidation capability of the bulk in electrochemical treatments in chloride media, because of the non-electrochemical absorption/hydrolysis processes. This is an example of chemical activation of oxidants, although it is not the most relevant in EAOP because this position is occupied by

- The synergistic interactions of oxidants, some of them (such as the combination of ozone and hydrogen peroxide) leading to the formation of hydroxyl radicals:

$$
\mathrm{H}_{2} \mathrm{O}_{2}+2 \mathrm{O}_{3} \leftrightarrows 2 \cdot \mathrm{OH}+3 \mathrm{O}_{2}
$$

- decomposition of hydrogen peroxide into hydroxyl radicals by iron (and cupper, as well, although it is less used)

$$
\mathrm{H}_{2} \mathrm{O}_{2}+\mathrm{Fe}^{2+} \leftrightarrows \mathrm{Fe}^{3+} \mathrm{OH}^{-}+\cdot \mathrm{OH}
$$

Due to the low solubility of iron species, the second case can be combined with coagulation and two very significant and different processes can be distinguished: Electro-Fenton and peroxi-coagulation.

The Fenton's reaction takes place at acidic conditions, the recommended range is an aqueous $\mathrm{pH} 2$ to 4 . This can be explained using a thermodynamic study. The existence of $\mathrm{Fe}(\mathrm{II})$ and $\mathrm{Fe}$ (III) complexes in aqueous solution has been reported $[78,79]$. Using this information, the iron distribution diagrams of chemical species can be calculated using the MEDUSA program [80] as Figures 3 and 4 show.

Note in Figure 4 that $\mathrm{Fe}^{3+}$ ions and the mononuclear species $\mathrm{Fe}(\mathrm{OH})^{2+}$ and $\mathrm{Fe}(\mathrm{OH})_{2}^{+}$predominates in acid solution and while $\mathrm{Fe}^{3+}$ decreases, the mononuclear species reach $67 \%$ and $18 \%$ of relatively fraction as the $\mathrm{pH}$ increases. Beyond $\mathrm{pH} 3$, insoluble species appear and the species $\mathrm{Fe}(\mathrm{OH})_{3(\mathrm{~s})}$ reach their maximum at $\mathrm{pH}$ near 4 .

Electro-Fenton is an indirect electrochemical method that is quite powerful in destroying organic pollutants in solution, and it requires the addition of iron salts into solution. This method is also the basis for the next one: peroxi-coagulation [81].Thus, for a clear understanding in the electrochemical and chemical reactions and the differences between methods the Electro-Fenton is described first.

In the Electro-Fenton process molecular oxygen and ferric ions are simultaneously reduced. Oxygen cathodic reduction in acidic media can be achieved using as electrode graphite causing oxygen reduction and producing $\mathrm{H}_{2} \mathrm{O}_{2}$ as eq. (40) shows [82].

$$
\mathrm{O}_{2}(\mathrm{~g})+2 \mathrm{H}^{+}+2 \mathrm{e}^{-} \leftrightarrows \mathrm{H}_{2} \mathrm{O}_{2}
$$
Eq. 41.

\begin{tabular}{|c|c|c|c|c|}
\hline Type of wastewater & Electrode/ electrochemical cell & Operation conditions & $\begin{array}{l}\text { Efficiency /main results obtained } \\
\text { in terms of treatability }\end{array}$ & Ref. \\
\hline $\begin{array}{l}\text { Dye contaminated } \\
\text { aqueous solution }\end{array}$ & $\begin{array}{l}\mathrm{TiO}_{2} \text { electrodes and } \mathrm{Co} \text { and } \\
\mathrm{Ni} \text { doped } \mathrm{TiO}_{2} \text { anodes, glassy } \\
\text { carbon cathode }\end{array}$ & $\begin{array}{l}\text { Potential difference }-0.95 \mathrm{~V} \\
\text { between carbon and } \mathrm{Hg} / \mathrm{HgSO}_{4} \\
\text { reference electrode }\end{array}$ & $90 \%$ color removal in $10 \mathrm{~min}$ & [180] \\
\hline Textile wastewater & $\begin{array}{l}\text { Open and undivided cell using } \\
\text { graphite felt (cathode) and } \\
\text { Pt (anode) in the presence of } \\
\text { copper ions }\end{array}$ & $\begin{array}{l}\mathrm{pH}=4 \text {, dissolved oxygen } 7.8-7.9 \\
\mathrm{mg} / \mathrm{L} \text {, applied current } 250 \mathrm{~mA} \text {, } \\
7 \mathrm{mM} \mathrm{Cu}^{2+} \text { concentration }\end{array}$ & $\begin{array}{l}67.9 \% \text { decolorization and } 56.3 \% \\
\text { COD removal after } 210 \text { minutes }\end{array}$ & [181] \\
\hline Landfill leachate & $\begin{array}{l}\text { Pt plate as anode and carbon- } \\
\text { PTFE as cathode }\end{array}$ & $\mathrm{pH} 7,0.05 \mathrm{M} \mathrm{Na}_{2} \mathrm{SO}_{4}$ solution & $\begin{array}{l}87 \% \text { of the TOC was removed } \\
\text { after } 4 \mathrm{~h}\end{array}$ & [177] \\
\hline Dye wastewater & $\begin{array}{l}\text { Carbon/polytetrafluoroethylene } \\
\text { (C/PTFE) cathode with a } \\
\text { terylene diaphragm }\end{array}$ & $\begin{array}{l}\text { steady concentration of } 8.3 \\
\mathrm{mg} / \mathrm{L} \mathrm{H}_{2} \mathrm{O}_{2} \text { in the cathodic } \\
\text { compartment after } 80 \mathrm{~min}\end{array}$ & $80 \%$ COD removal & [182] \\
\hline
\end{tabular}

The ferric ion is also reduced to ferrous ions as shown in

$$
\mathrm{Fe}^{3+}+\mathrm{e}^{-} \leftrightarrows \mathrm{Fe}^{2+}
$$

The Fenton's reaction occurs when ferrous ions react with hydrogen peroxide as shown in Eq. 42.

Table 8. Treatment of industrial wastewater with hydrogen peroxide produced by electrolysis. 


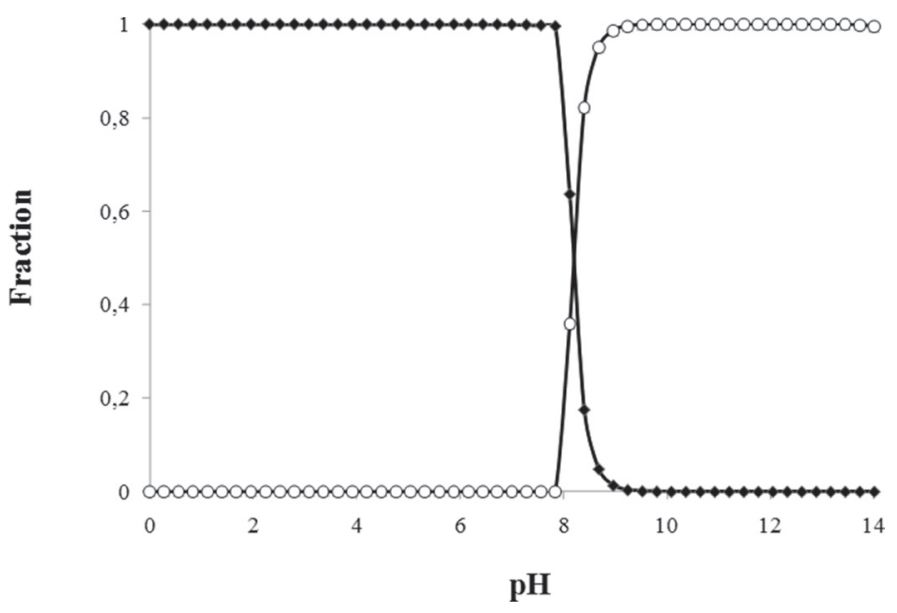

Figure 3. Predominance zone diagram for Fe(II) chemical species in aqueous solution. $(\diamond) \mathrm{Fe}^{2+},(\circ) \mathrm{Fe}(\mathrm{OH})_{2(\mathrm{~s})}$.

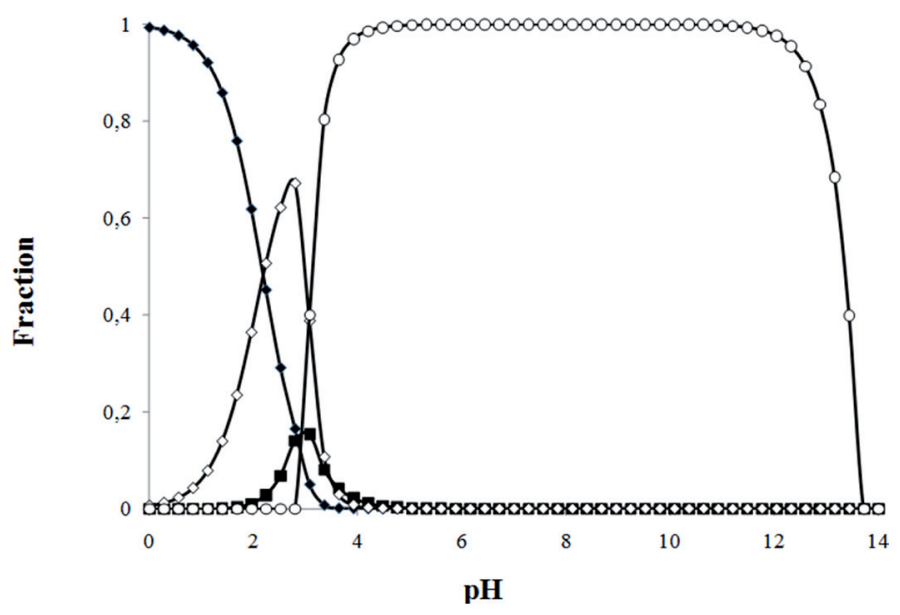

Figure 4. Predominance zone diagram for $\mathrm{Fe}(\mathrm{III})$ chemical species in aqueous solution. $(\diamond) \mathrm{Fe}^{3+},(0) \mathrm{Fe}(\mathrm{OH})_{3(\mathrm{~s})},(\diamond) \mathrm{Fe}(\mathrm{OH})^{2+}(\mathbf{\square})$ $\mathrm{Fe}(\mathrm{OH})_{2}^{+}$.

$$
\mathrm{Fe}^{2+}+\mathrm{H}_{2} \mathrm{O}_{2} \rightarrow \mathrm{Fe}^{3+}+\mathrm{OH}^{-}+\cdot \mathrm{OH}
$$

Organic molecules are destroyed by the action of ${ }^{\circ} \mathrm{OH}$ radicals produced in the aqueous media. The hydroxyl radical can react with organic matter as reaction (43) indicates.

$$
\mathrm{RH}+{ }^{\bullet} \mathrm{OH} \rightarrow \mathrm{R}^{\bullet}+\mathrm{H}_{2} \mathrm{O}
$$

Therefore, the main advantage of adding and electrogenerating $\mathrm{H}_{2} \mathrm{O}_{2}$ is to produce this hydroxyl radical which will react with the organic pollutants present in the wastewater. The organic radical can react with oxygen or with a hydroxyl radical to produce oxidation products, as shown in reaction (44) and (45).

$$
\begin{gathered}
\mathrm{R}^{\bullet}+\mathrm{O}_{2} \rightarrow \text { products } \\
\mathrm{R}^{\bullet}+{ }^{\bullet} \mathrm{OH} \rightarrow \text { products }
\end{gathered}
$$

The Fenton's reagent $\left(\mathrm{H}_{2} \mathrm{O}_{2}, \mathrm{Fe}^{2+}\right)$ is generated in situ and electrochemically catalyzed, since the produced $\mathrm{Fe}^{3+}$ can be reduced again to $\mathrm{Fe}^{2+}$.

The Electro-Fenton process presents the following advantages: no addition of chemical reagents except a catalytic quantity of ferrous ions, no pollution displacement to another medium and a complete degradation of organic pollutants [8387].

The peroxi-coagulation process uses a sacrificial iron anode to supply $\mathrm{Fe}^{2+}$ ions into aqueous solution and graphite is used as cathode, an oxidizing agent is produced in situ. These two species react in aqueous solution as eq. 46 shows:

$$
\mathrm{Fe}^{2+}+\mathrm{H}_{2} \mathrm{O}_{2}+\mathrm{H}^{+} \rightarrow \mathrm{Fe}^{3+}+{ }^{\cdot} \mathrm{OH}+\mathrm{H}_{2} \mathrm{O}
$$

The main advantage in this process is the use of sacrificial $\mathrm{Fe}$ anode which is electrodissolved supplying stoichiometric amount of $\mathrm{Fe}^{2+}$, which reacts with electrogenerated $\mathrm{H}_{2} \mathrm{O}_{2}$ so the contaminants are removed by their degradation with ${ }^{\circ} \mathrm{OH}$ in aqueous solution and their coagulation with the formation of $\mathrm{Fe}(\mathrm{OH})_{3}(\mathrm{~s})$. The $\mathrm{H}_{2} \mathrm{O}_{2}$ produced in peroxi-coagulation is completely consumed due to its fast reaction with the high $\mathrm{Fe}^{2+}$ concentration present in the medium giving a high concentration of oxidizing ${ }^{\circ} \mathrm{OH}$. It has been reported that efficient degradation of azo compounds can be achieved by this method compared with electrocoagulation [88-93].

Synergistic combination of oxidants is carried out typically in many electrochemical cells. Hydrogen peroxide and ozone are typically formed during electrolysis, directly on the surface of by the action of hydroxyl radicals.

Table 9 presents some of the applications of Electro-Fenton and peroxicoagulation processes that have been recently investigated.

\section{Activation of oxidants produced in electrochemical processes by irradiation of light}

Light irradiation could enhance the effectiveness of many oxidants produced on the nearness of the electrode surface either by direct electron transfer on the electrode surface or by the action of hydroxyl radicals. Photo-activation of electrochemically generated reactive species, such as $\mathrm{H}_{2} \mathrm{O}_{2}$ or $\mathrm{O}_{3}$, by reactions such as those proposed in eq. 47 and 48 could increase the efficiency of the process though homogeneous catalysis.

$$
\begin{gathered}
\mathrm{H}_{2} \mathrm{O}_{2}+\mathrm{O}_{3} \stackrel{\mathrm{hv}}{\longrightarrow} 2{ }^{\bullet} \mathrm{OH} \\
\mathrm{H}_{2} \mathrm{O}+\mathrm{O}_{3} \stackrel{\mathrm{hv}}{\longrightarrow} 2{ }^{\bullet} \mathrm{OH}+\mathrm{O}_{2}
\end{gathered}
$$

Thus, sulfate radicals and many other strongly-energetic species, in addition to hydroxyl radicals generated by ozone and hydrogen peroxide light assisted decomposition are expected to be produced. The production of sulfate radical from persulfate by light irradiation is shown in eq $(49)[94,95]$. It is worth to take into account that the sulfate radical reacts typically $10^{3}-10^{5}$ times faster than the persulfate [96]. 
Table 9. Treatment of industrial wastewater with Electro-Fenton and peroxicoagulation.

\begin{tabular}{|c|c|c|c|c|}
\hline Type of wastewater & Electrode/ electrochemical cell & Operation conditions & $\begin{array}{l}\text { Efficiency /main results obtained } \\
\text { in terms of treatability }\end{array}$ & Ref. \\
\hline \multicolumn{5}{|c|}{ Electro-Fenton } \\
\hline Landfill leachate & Sacrificial iron anode & $\mathrm{pH} 3.0$ & $\begin{array}{l}72 \% \text { COD removal in } 20 \\
\text { minutes }\end{array}$ & [184] \\
\hline Olive oil mill wastewater & Sacrificial iron anode & $\mathrm{pH} 3.0$ & Mineralization in $9 \mathrm{~h}$ at $200 \mathrm{~mA}$ & [185] \\
\hline $\begin{array}{l}\text { Flame retardant industry } \\
\text { wastewater }\end{array}$ & Sacrificial iron anode & \multirow[t]{2}{*}{$\mathrm{pH} 1.5$} & 99.9 removal of P-compunds & [149] \\
\hline $\begin{array}{l}\text { Petrochemical industry } \\
\text { wastewater }\end{array}$ & Sacrificial iron anode & & $94 \% \mathrm{COD}$ removal in $5 \mathrm{~h}$ & [86] \\
\hline $\begin{array}{l}\text { Slaughterhouse } \\
\text { wastewater }\end{array}$ & Sacrificial iron anode & $\begin{array}{l}\mathrm{pH} 7.8,6 \% \mathrm{H}_{2} \mathrm{O}_{2} \text {, current } \\
\text { density } 20 \mathrm{~mA} \mathrm{~cm}^{-2}\end{array}$ & $\begin{array}{l}81 \% \text { COD removal, } 91 \% \\
\text { turbidity removal }\end{array}$ & {$[186]$} \\
\hline Dairy industry wastewater & $\begin{array}{l}\text { Iron anode and aluminum } \\
\text { cathode }\end{array}$ & $\begin{array}{l}\mathrm{pH} 6.5-7.0 \text {, current density } \\
15 \mathrm{~mA} \mathrm{~cm}^{-2} \text {, external } \mathrm{H}_{2} \mathrm{O}_{2} \\
\text { addition } 3 \times 1000 \mathrm{mg} \mathrm{L}^{-1}\end{array}$ & $\begin{array}{l}75 \% \text { COD removal, } 91 \% \\
\text { turbidity removal }\end{array}$ & [187] \\
\hline Landfill leachate & Anode $\left(\mathrm{Ti} / \mathrm{RuO}_{2}-\mathrm{IrO}_{2}\right)$ & $\begin{array}{l}\mathrm{pH} 3,0.34 \mathrm{~mol} / \mathrm{L} \mathrm{H}_{2} \mathrm{O}_{2}, 0.028 \\
\mathrm{~mol} / \mathrm{L} \mathrm{Fe}^{2+} \text {, current } 2 \mathrm{~A}\end{array}$ & $80 \%$ COD removal & [188] \\
\hline $\begin{array}{l}\text { Alcohol distillery } \\
\text { wastewater }\end{array}$ & iron electrodes & $\begin{array}{l}\mathrm{pH} 4 \text {, current density } 60 \mathrm{~mA} \\
\mathrm{~cm}^{-2}, 0.3 \mathrm{M} \mathrm{Na}_{2} \mathrm{SO}_{4} \text { and } 60.000 \\
\mathrm{mg} \mathrm{L}^{-1} \mathrm{H}_{2} \mathrm{O}_{2}\end{array}$ & $\begin{array}{l}\text { COD removal efficiency of } \\
92.6 \% \text { TOC removal efficiency } \\
\text { of } 88.7 \%\end{array}$ & [189] \\
\hline $\begin{array}{l}\text { Photographic processing } \\
\text { wastewater }\end{array}$ & $\begin{array}{l}\text { BDD anode, carbon felt } \\
\text { cathode. Single compartment } \\
\text { cylindrical cell }\end{array}$ & $\mathrm{pH} 3$, current $300 \mathrm{~mA}$ & $90 \%$ TOC removal & [190] \\
\hline $\begin{array}{l}\text { Photographic processing } \\
\text { wastewater }\end{array}$ & $\begin{array}{l}\text { Pt anode, carbon felt cathode. } \\
\text { Single compartment cylindrical } \\
\text { cell }\end{array}$ & $\mathrm{pH} 3$, current $300 \mathrm{~mA}$ & $30 \%$ TOC removal & [190] \\
\hline Wastewater & Platinized titanium electrode & $\begin{array}{l}\text { Current density } 340 \mathrm{~mA} \mathrm{~cm}{ }^{-2} \text {, } \\
\text { ratio Fenton reagent to } \mathrm{H}_{2} \mathrm{O}_{2} \\
1: 20\end{array}$ & $\begin{array}{l}100 \% \mathrm{COD} \text { and } \mathrm{NH} 4+\text { removal } \\
\text { after } 4 \mathrm{~h}\end{array}$ & [191] \\
\hline Olive mill wastewater & & $\begin{array}{l}\mathrm{pH} 6.5, \mathrm{H}_{2} \mathrm{O}_{2} \mathrm{~g} \mathrm{~L}^{-1} \text {, current } \\
20 \mathrm{~A}\end{array}$ & $52 \%$ COD removal & [192] \\
\hline Tannery wastewater & Iron cathode and anode & $\begin{array}{l}\mathrm{pH} 5,1670 \mathrm{mg} \mathrm{L}^{-1} \mathrm{H}_{2} \mathrm{O}_{2} \\
\text { energy consumption } 15 \mathrm{~W}\end{array}$ & $70 \%$ COD removal in $10 \mathrm{~min}$ & [193] \\
\hline Landfill leachate & Aluminium electrodes & $\begin{array}{l}\mathrm{pH} 3, \mathrm{Fe}^{2+} / \mathrm{H}_{2} \mathrm{O}_{2} \text { molar ratio } 1 \\
\text { current density } 49 \mathrm{~mA} \mathrm{~cm}-\end{array}$ & $\begin{array}{l}94 \% \text { COD removal and } 95 \% \\
\text { color removal in } 43 \mathrm{~min}\end{array}$ & [194] \\
\hline Landfill leachate & Aluminun electrodes & $\begin{array}{l}\mathrm{pH} 3, \mathrm{H}_{2} \mathrm{O}_{2} / \mathrm{Fe}^{2+} \text { molar ratio } 1, \\
28^{\circ} \mathrm{C}\end{array}$ & $\begin{array}{l}75 \% \text { coliform bacteria removal, } \\
85 \% \text { COD removal }\end{array}$ & [195] \\
\hline Landfill leachate & $\begin{array}{l}\text { Cast iron anode and cathode } \\
\text { Electrodes }\end{array}$ & $\mathrm{pH} 4,750 \mathrm{mg} \mathrm{L}^{-1} \mathrm{H}_{2} \mathrm{O}_{2}$ & $85 \%$ COD removal & [196] \\
\hline $\begin{array}{l}\text { Rayon industry } \\
\text { wastewater }\end{array}$ & $\begin{array}{l}\text { Graphite cathode and iron } \\
\text { anode }\end{array}$ & $\begin{array}{l}\mathrm{H}_{2} \mathrm{O}_{2} \text { dose of } 1530 \mathrm{mg} \mathrm{L}^{-1} \\
\text { current density of } 0.90 \mathrm{~A} \mathrm{dm}^{-2}\end{array}$ & $\begin{array}{l}88 \% \text { COD was reduced in } 50 \\
\text { min }\end{array}$ & [197] \\
\hline $\begin{array}{l}\text { Fertilizer manufacturing } \\
\text { wastewater }\end{array}$ & $\begin{array}{l}\text { Iron anode and aluminum } \\
\text { cathode }\end{array}$ & $\begin{array}{l}\mathrm{pH} 3, \mathrm{H}_{2} \mathrm{O}_{2} 25 \mathrm{mM} \text {, current } \\
\text { density of } 50 \mathrm{~A} \mathrm{~m}^{-2}\end{array}$ & $\begin{array}{l}83 \% \text { COD removal and } 79 \% \\
\text { TOC removal after } 45 \mathrm{~min}\end{array}$ & [198] \\
\hline Petrochemical wastewater & $\begin{array}{l}\text { Stainless steel anode and } \\
\text { cathode }\end{array}$ & $\begin{array}{l}\mathrm{pH} 3.5 \text {, addition } \mathrm{H}_{2} \mathrm{O}_{2} 800 \mathrm{mg} \\
\mathrm{L}^{-1}\end{array}$ & $87 \%$ COD removal & [199] \\
\hline Dyeing wastewater & $\begin{array}{l}\text { Activated carbon fiber cloth } \\
\text { anode }\end{array}$ & $\begin{array}{l}\mathrm{pH} \mathrm{3} \text {, current density } 3.2 \mathrm{~mA} \\
\mathrm{~cm}^{-2}\end{array}$ & $70 \%$ COD removal after $240 \mathrm{~min}$ & [200] \\
\hline \multicolumn{5}{|c|}{ Peroxicoagulation } \\
\hline Textile dye solution & $\begin{array}{l}\text { Sacrificial iron anode, Carbon } \\
\text { nanotube-PTFE electrode }\end{array}$ & $\mathrm{pH} 3$, current $200 \mathrm{~mA}$ & $95 \%$ color removal in $16 \mathrm{~min}$ & [201] \\
\hline $\begin{array}{l}\text { Pharmaceutical } \\
\text { wastewater }\end{array}$ & $\begin{array}{l}\text { Sacrificial iron anode, Iron } \\
\text { cathode }\end{array}$ & $\begin{array}{l}\mathrm{pH} \mathrm{7,} \mathrm{current} \mathrm{density} 1.9 \mathrm{~mA} \\
\mathrm{~cm}^{-2}\end{array}$ & $55 \% \mathrm{COD}$ removal after $1 \mathrm{~h}$ & [202] \\
\hline Dye solution & $\begin{array}{l}\text { Iron anode and gas-diffusion } \\
\text { cathode }\end{array}$ & $\begin{array}{l}\mathrm{pH} 3,0.05 \mathrm{M} \mathrm{Na}_{2} \mathrm{SO}_{4} \text {, current } \\
100 \mathrm{~mA}\end{array}$ & $62 \%$ color removal in $10 \mathrm{~min}$ & [203] \\
\hline
\end{tabular}




$$
\mathrm{S}_{2} \mathrm{O}_{8}^{2-} \stackrel{\text { hv }}{\longrightarrow} 2 \mathrm{SO}_{4}^{-\bullet}
$$

Production of radicals from chlorine has been also described in literature [97, 98], being demonstrated that under non extreme $\mathrm{pH}$, hydroxyl and chlorine radicals are the main end products resulting of the light assisted degradation of hypochlorite.

$$
\begin{gathered}
\mathrm{ClO}^{-} \stackrel{\mathrm{hv}}{\longrightarrow} \mathrm{O}^{-\bullet}+\mathrm{Cl}^{\bullet} \\
\mathrm{O}^{-\bullet}+\mathrm{H}_{2} \mathrm{O} \longrightarrow \mathrm{OH}^{-}+{ }^{\bullet} \mathrm{OH}
\end{gathered}
$$

In literature, it has been also described the enhancement of electrolysis of organics with conductive-diamond electrodes, by irradiation of direct light to the surface of the diamond anode, due to the decomposition of the oxidants generated. To do that, a novel cell design was developed and the effects of chloride and sulfate media on results were described taking into account that hypochlorite and persulfates were formed during the oxidation [99].

Table 10 indicates the use of PEC in the removal of some pollutants with different electrodes.

\section{Activation of oxidants produced in electrochemical processes by irradiation of ultrasound}

During the last century, ultrasound irradiation has been used as an effective method for many applications including cleaning, sterilization, drying, degassing, homogenization, extraction, enhancement for chemical reactions, etc. Ultrasound irradiation consists of oscillating sound pressure waves with a frequency greater than the upper limit of human hearing $(20,000$ Hertz). Its action on chemicals is due to the ultrasonic cavitation, a phenomena caused by the formation, growth, and implosive collapse of bubbles generated when the liquid bulk is irradiated with ultrasound. The collapse of bubbles takes place in very short period of time [100] and, therefore, it can be considered as adiabatic. Because of that, high temperatures and pressures are reached within the bubble due to the gas compression. This causes a huge concentration of energy in a very small place, generating a hot spot, which results in a drastic local increment of the temperature reaching several thousands of Kelvin [101]. This energy is later on dispersed to the environment, which quickly reduces the temperature and the hot spot returns to the ambient value. However, during a fraction of time, the very high temperature reached can produce significant changes in the chemical composition and to generate new radical species and components. This generation can be controlled by the dose of chemical species, in particular gases, although it must be taken into account that this addition may decrease the temperature of the hot spot. These results indicates that the gas molecules react, generating molecules that easily form radicals, such as oxygen, and therefore increasing the reactivity of the system [102].

In literature, one of the novel applications of ultrasound irradiation is the degradation of pollutants contained in wastewaters. It has been reported a work studying the destruction of six phthalates at low concentrations $\left(240 \mu \mathrm{g} \mathrm{dm}^{-3}\right)$ [103]. This study revealed that ultrasound irradiation was able to remove the four higher molecular mass phthalates studied (di-n-butyl phthalate, butylbenzyl phthalate, di-(2-ethylhexyl) phthalate and di-n-octyl phthalate) within 30-60 min of irradiation. However, the lowest molecular weight phthalates studied (dimethyl phthalate and diethyl phthalate) required much longer irradiation times to be removed, indicating that they were more recalcitrant. This different behavior could be explained because of the different hydrophobicity of the phthalates studied.

Additionally to the applications combining ultrasound irradiation and chemistry (sonochemistry), there are many other applications combining ultrasound irradiation and electrochemistry (sonoelectrochemistry). Therefore, in the recent years, many works have been focused on sonoelectrosynthesis [104, 105], sonovoltammetry [106, 107], electrodeposition [108] electrode coating $[109,110]$ and electroanalysis $[111,112]$, etc.

Combination of ultrasound irradiation with electrolysis seems to be an interesting topic. Because of that, sono-electrolysis processes have also been widely studied in the recent years, being proposed as an adequate alternative for the treatment of different kind of wastewaters, leading to good removal efficiencies [106, 113-116]. Results obtained in these works indicate that ultrasound irradiation could be used to enhance mass transfer and to produce changes in the chemical composition of the electrolyte because of the cavitation phenomenon. This process can produce new radical species and components based on the very high pressure and temperature reached, during the implosive collapse of bubbles, when the system is irradiated with ultrasound [101, 102]. Both changes are complementary and even synergistic with the typical ones taking place during

\begin{tabular}{|c|c|c|c|c|}
\hline Type of wastewater & Electrode/ electrochemical cell & Operation conditions & $\begin{array}{l}\text { Efficiency /main results obtained } \\
\text { in terms of treatability }\end{array}$ & Ref. \\
\hline Landfill leachate & DSA anode & $\begin{array}{l}\text { UV light irradiation, current } \\
\text { density } 67.1 \mathrm{~mA} \mathrm{~cm}^{-2}\end{array}$ & $74 \%$ COD removal & [204] \\
\hline $\begin{array}{l}\text { Dye contaminated } \\
\text { aqueous solution }\end{array}$ & $\begin{array}{l}\text { Co and Ni doped } \mathrm{TiO}_{2} \\
\text { electrodes and } \mathrm{TiO}_{2} \text { electrodes }\end{array}$ & UV lamp $365 \mathrm{~nm}, 750 \mu \mathrm{W} \mathrm{cm} \mathrm{cm}^{-2}$ & $90 \%$ color removal in $10 \mathrm{~min}$ & [180] \\
\hline Landfill leachate & $\begin{array}{l}\text { Cast iron anode and cathode } \\
\text { electrodes }\end{array}$ & $\begin{array}{l}\text { pH 3, UV lamp } 4 \mathrm{~W}, 2000 \mathrm{mg} \\
\mathrm{l}^{-1} \mathrm{H}_{2} \mathrm{O}_{2}\end{array}$ & $70 \%$ COD removal & [205] \\
\hline
\end{tabular}
electrolysis, which results in a more effective process.

Table 10. Treatment of industrial wastewater with photo irradiation assisted electrolysis. 
During the last years, electrolytic technologies have been deeply studied and applied for the treatment of many kinds of wastewaters. This has been promoted by the development of the conductive-diamond anode on p-Si support, a novel electrode material with very good properties $[16,18,20,117]$. The robustness of this technology able to remove all organic pollutants known and its efficiency (100\% current efficiency in the treatment of wastewaters when working down to 1000-2000 $\mathrm{mg} \mathrm{dm}{ }^{-3}$, the typical discharge limit of municipal sewers) are the two major advantages of this technology. The very good performance of this technology can be explained by the production and efficient participation of hydroxyl radicals in the destruction of pollutants $[15,118]$. Moreover, it also promotes the generation of many other oxidants, enhancing the current efficiencies significantly with respect to the electrolysis with other anode materials. Its main drawback is low current efficiencies attained in the oxidation of low concentration of pollutants. This can be explained by the appearance of a limiting stage in the reaction caused by the mass transfer of pollutant from the liquid bulk to the anode surface. In this sense, the association of ultrasound with electrolysis seems to be a promising alternative to avoid the inefficiencies, because sono-electrolysis has shown to be able to improve the mass transfer rate and to promote the decomposition of water producing hydroxyl radicals and many oxidants from the interaction of these radicals with other species containing in the wastewater $[25,71,119$, 120].

In literature it has been described the degradation of dimethyl phthalate by electrolysis and sono-electrolysis with conductive-diamond electrodes. Dimethyl phthalate is a wellknown plasticizer, widely found in wastewaters, hard to oxidize by ultrasound irradiation [103] and with an oxidation widely studied by many advanced oxidation processes [121, 122], including electrolysis with diamond [123]. Recently, it has been described the oxidation by sono-electrolysis with great efficiencies [124].

Table 11 summarizes the use of sonoelectrolisis in the removal of some pollutants contained in actual industrial wastes.

\section{Conclusions}

The Electrochemical Advanced Oxidation Processes deals with the use of hydroxyl radical to attack the pollutants present in wastewater. This radical can be produced at the electrode surface such as in the direct electro-oxidation processes or in bulk solution such as in the indirect electrolytic processes. The aim in either case is to try to mineralize the pollutants. This technology should be used for the following reasons:

- Good quality of the treated wastewater for recycling into the original production process.

- Eliminate a further polishing water steps. Avoid the sludge generation and the need for sludge final disposal methods and the involved environmental impact.

- In the real applications, the AOP has been used to mineralize pollutants difficult to be oxidize by means of other processes such as those contained in textile, tannery, petrochemical and pharmaceutical wastewaters amongst others.

\section{Acknowledgments}

The authors wish to acknowledge the support given by the Sistema Nacional de Investigadores (SNI), Mexico, and the

Table 11. Treatment of industrial wastewater with ultrasound irradiation assisted electrolysis.

\begin{tabular}{|c|c|c|c|c|}
\hline Type of wastewater & Electrode/ electrochemical cell & Operation conditions & $\begin{array}{l}\text { Efficiency /main results obtained } \\
\text { in terms of treatability }\end{array}$ & Ref. \\
\hline Dye effluent & Pt electrodes & $\begin{array}{l}40^{\circ} \mathrm{C} \text {, current } 60 \mathrm{~mA}, 0.01 \mathrm{~mol} \\
\mathrm{~L}^{-1} \mathrm{NaCl} \text {, ultrasound } 20 \mathrm{kHz}\end{array}$ & $95 \%$ COD removal & [106] \\
\hline Cyan ink effluent & mild steel electrodes & $18 \mathrm{~V}$ and $1 \mathrm{~A}$. & $20 \% \mathrm{COD}$ removal after $3 \mathrm{~h}$ & [115] \\
\hline Saline wastewater & - & - & $\begin{array}{l}\text { Significant level of pollution } \\
\text { attenuation was attained during } \\
\text { first } 15 \text { minutes of electro- } \\
\text { sonication. Power higher } \\
\text { than } 100 \mathrm{~W} \text { did not render a } \\
\text { significant increase in efficiency }\end{array}$ & [206] \\
\hline Azo dyes effluent & Pt anode & $\begin{array}{l}\mathrm{pH} 6, \mathrm{Na}_{2} \mathrm{SO}_{4} \text { as electrolyte, } \\
25^{\circ} \mathrm{C}, 22 \mathrm{kHz}\end{array}$ & $90 \%$ removal after 6 minutes & [207] \\
\hline Winery wastewater & & & $\begin{array}{l}77 \% \text { COD removal } \\
\text { when combining with } \\
\text { electrocoagulation and } \\
\text { ozonation-UV processes }\end{array}$ & [208] \\
\hline $\begin{array}{l}\text { Synthetic textile } \\
\text { wastewater }\end{array}$ & Cast iron plate electrodes & $\begin{array}{l}\mathrm{pH} 3,35 \mathrm{kHz}, \mathrm{DC} \text { current } 250 \\
\mathrm{~mA}, 800 \mathrm{mg} \mathrm{L}^{-1} \mathrm{H}_{2} \mathrm{O}_{2}\end{array}$ & $95 \%$ COD removal & [209] \\
\hline
\end{tabular}


financial support of the Consejo Nacional de Ciencia y Tecnologia (CONACYT), Mexico by Grant \# 153828. Financial support of the Spanish government through project CTM201018833 is gratefully acknowledged.

\section{References}

1. Weber, W. J. Physicochemical processes for water quality control. New York: Wiley - Inter sciences, 1972.

2. Barrera-Diaz, C., et al. Industrial \& Engineering Chemistry Research 2012, 51, 9335-9342.

3. Guelli Ulson de Souza, S. M. d. A.; Santos Bonilla, K. A.; Ulson de Souza, A. A. J. Haz. Mat. 2010, 179, 35-42.

4. Muhammad, A., et al. Braz. J. Chem. Eng. 2008, 25, 453-459.

5. Oller, I.; Malato, S.; Sanchez-Perez, J. A. Science of the Total Environment 2011, 409, 4141-4166.

6. Eckenfelder, W. W. Ind. Water Poll. Control New York: McGraw Hill, 1989.

7. Crittenden, J. C., et al. Water Treatment: Principles and Design. Hoboken, NJ.: Wiley, 2005.

8. Rajeshwar, K.; Ibanez, J. G., Academic Press, San Diego, 1997, xvi, $776 \mathrm{p}$.

9. Comninellis, C.; Chen, G. Electrochemistry for the Environment. New York, NY: Springer New York, 2010.

10. Sequeira, C. A. C., in: Studies in environmental science 59, Elsevier, Amsterdam ; New York, 1994, xxvii, 718 p.

11. Genders, J. D.; Weinberg, N. L. Electrochemistry for a Cleaner Environment. East Amherst: Electrosynthesis Company, 1992.

12. Bockris, J. O. M. The Electrochemistry of Cleaner Environments. New York: Plenum Press, 1972.

13. Parsons, S. A.; Williams, M., IWA Publishing, London (UK), 2004.

14. Brillas, E.; Sires, I.; Oturan, M. A. Chem. Rev. 2009, 109, 65706631.

15. Marselli, B., et al. J. Electrochem. Soc. 2003, 150, D79-D83.

16. Martinez-Huitle, C. A.; Brillas, E. Appl. Cat. B-Environmental 2009, 87, 105-145.

17. Panizza, M.; Cerisola, G. Chem. Rev. 2009, 109, 6541-6569.

18. Sires, I.; Brillas, E. Environm. Int. 2012, 40, 212-229.

19. Canizares, P., et al. Afinidad 2009, 66, 27-37.

20. Rodrigo, M. A., et al. Catalysis Today 2010, 151, 173-177.

21. Canizares, P., et al. Electrochem. Commun. 2008, 10, 602-606.

22. Guinea, E., et al. Appl. Cat. B-Environmental 2009, 89, 645-650.

23. Garcia-Segura, S., et al. J. Electroanal. Chem. 2012, 681, 36-43.

24. Hammami, S., et al. Desal. Water Treat. 2012, 45, 297-304.

25. Oturan, M. A., et al. J. Electroanal. Chem. 2008, 624, 329-332.

26. Foti, G., et al. Electrochem. Sol. State Lett. 1999, 2, 228-230.

27. Fujishima, A.; Honda, K. Nature 1972, 238, 37-+.

28. Frank, S. N.; Bard, A. J. J. Am. Chem. Soc. 1977, 99, 46674675.

29. Kaneko, M., et al. Electrochem. Commun. 2006, 8, 336-340.

30. Kaneko, M., et al. Biosensors \& Bioelectronics 2007, 23, 140 143.

31. Hirano, K., et al. J. Photochem. Photobiol. a-Chemistry 2000, 136, 157-161.

32. Kaneko, M., et al. J. Electroanal. Chem. 2004, 572, 21-27.

33. Nemoto, J., et al. J. Electroanal. Chem. 2007, 599, 23-30.

34. Pelegrini, R., et al. J. Appl. Electrochem. 2000, 30, 953-958.

35. Pelegrini, R., et al. Appl. Cat. B-Environmental 1999, 22, 83-90.

36. Catanho, M.; Malpass, G. R. P.; Motheo, A. J. Appl. Cat. B-Environmental 2006, 62, 193-200.

37. Socha, A.; Chrzescijanska, E.; Kusmierek, E. Dyes and Pigments 2005, 67, 71-75.

38. Socha, A., et al. Coloration Technology 2006, 122, 207-212.

39. Socha, A., et al. Dyes and Pigments 2007, 73, 390-393.
40. de Freitas, A. M.; Sirtori, C.; Peralta-Zamora, P. Environm. Chem. Lett. 2011, 9, 97-102.

41. Pinhedo, L., et al. Appl. Cat. B-Environmental 2005, 57, 75-81.

42. Li, G. T., et al. Water Research 2006, 40, 213-220.

43. Zanoni, M. V. B.; Sene, J. J.; Anderson, M. A. J. Photochem. Photobiol. a-Chemistry 2003, 157, 55-63.

44. Osugi, M. E., et al. Electrochim. Acta 2005, 50, 5261-5269.

45. Zhao, X., et al. Appl. Cat. B-Environmental 2009, 91, 539-545.

46. Panizza, M.; Cerisola, G. Electrochim. Acta 2003, 48, 15151519.

47. Hastie, J., et al. Ind. Eng. Chem. Res. 2006, 45, 4898-4904.

48. Cabeza, A.; Urtiaga, A. M.; Ortiz, I. Ind. Eng. Chem. Res. 2007, 46, 1439-1446.

49. Mascia, M., et al. J. Haz. Mat. 2010, 174, 314-322.

50. Brillas, E., et al. Chemosphere 2005, 58, 399-406.

51. Panizza, M.; Cerisola, G. Electrochim. Acta 2005, 51, 191-199.

52. Guinea, E., et al. Water Research 2009, 43, 2131-2138.

53. Canizares, P., et al. J. Haz. Mat. 2007, 146, 552-557.

54. Canizares, P., et al. Ind. Eng. Chem. Res. 2009, 48, 1298-1301.

55. Bergmann, M. E. H.; Rollin, J.; Iourtchouk, T. Electrochim. Acta 2009, 54, 2102-2107.

56. Sanchez-Carretero, A., et al. Chem. Eng. J. 2011, 166, 710-714.

57. Saha, M. S.; Furuta, T.; Nishiki, Y. Electrochem. Sol. State Lett. 2003, 6, D5-D7.

58. Ravera, M., et al. Chemosphere 2004, 57, 587-594.

59. Panizza, M.; Cerisola, G. J. Haz. Mat. 2008, 153, 83-88.

60. Gandini, D., et al. J. Appl. Electrochem. 2000, 30, 1345-1350.

61. Serrano, K., et al. Electrochim. Acta 2002, 48, 431-436.

62. Saez, C., et al. J. Appl. Electrochem. 2010, 40, 1715-1719.

63. Li, C.; Li, X. Z.; Graham, N. Chemosphere 2005, 61, 537-543.

64. Delaude, L.; Laszlo, P. J. Org. Chem. 1996, 61, 6360-6370.

65. He, W. C., et al. Electrochim. Acta 2006, 51, 1967-1973.

66. Deluca, S. J.; Cantelli, M.; Deluca, M. A. Water Sci. Technol. 1992, 26, 2077-2080.

67. Jiang, J. Q.; Lloyd, B. Water Research 2002, 36, 1397-1408.

68. Gilbert, M. B.; Waite, T. D.; Hare, C. J. Am. Water Works Assoc. 1976, 68, 495-497.

69. Basu, A.; Williams, K. R.; Modak, M. J. J. Biol. Chem. 1987, 262, 9601-9607.

70. Saez, C.; Rodrigo, M. A.; Canizares, P. Aiche Journal 2008, 54, 1600-1607.

71. Canizares, P., et al. Electrochem. Commun. 2007, 9, 2286-2290.

72. Foller, P. C.; Bombard, R. T. J. Appl. Electrochem. 1995, 25, 613627.

73. Oturan, M. A. J. Appl. Electrochem. 2000, 30, 475-482.

74. Brillas, E., et al. Electrochim. Acta 2004, 49, 4487-4496.

75. Peralta-Hernandez, J. M., et al. Water Research 2006, 40, $1754-$ 1762.

76. Bard, A. J.; Parsons, R.; Jordan, J. Standard Potentials in Aqueous Solution. New York: Marcel Dekker, 1985.

77. Eckenfelder, W. W. Industrial Water Pollution Control. New York: McGraw Hill, 1988.

78. Baes, C. F.; Mesmer, R. E. The hydrolysis of cations. New York: Wiley-Interscience, 1976.

79. Smith, M. R.; Martell, A. E., Plenum Press, USA, 1974.

80. Puigdomenech, I., Royal Institute of Technology, Stockolm, 1997.

81. Barrera-Diaz, C., et al. Sep. Purif. Rev. 2011, 40, 1-24.

82. Do, J. S.; Chen, C. P. J. Appl. Electrochem. 1994, 24, 936-942.

83. Oturan, M. A., et al. J. Electroanal. Chem. 2001, 507, 96-102.

84. Oturan, M. A., et al. Environm. Sci. Technol. 2000, 34, 34743479.

85. Oturan, M. A.; Pinson, J. J. Phys. Chem. 1995, 99, 1394813954.

86. Chou, S. S., et al. Water Research 1999, 33, 751-759.

87. Guivarch, E., et al. Environm. Chem. Lett. 2003, 1, 38-44.

88. Brillas, E., et al. Chemosphere 2003, 51, 227-235. 
89. Brillas, E.; Boye, B.; Dieng, M. M. J. Electrochem. Soc. 2003, 150, E148-E154.

90. Brillas, E.; Casado, J. Chemosphere 2002, 47, 241-248.

91. Brillas, E.; Sauleda, R.; Casado, J. J. Electrochem. Soc. 1997, 144, 2374-2379.

92. Boye, B.; Dieng, M. M.; Brillas, E. Electrochim. Acta 2003, 48, 781-790.

93. Boye, B.; Brillas, E.; Dieng, M. M. J. Electroanal. Chem. 2003, 540, 25-34.

94. Lin, Y.-T.; Liang, C.; Chen, J.-H. Chemosphere 2011, 82, 11681172.

95. Shih, Y.-J., et al. Chemosphere 2012, 89, 1262-1266.

96. Tsitonaki, A., et al. Crit. Rev. Environm. Sci. Technol. 2010, 40, 55-91.

97. Oliver, B. G.; Carey, J. H. Environm. Sci. Technol. 1977, 11, 893895.

98. Chan, P. Y.; El-Din, M. G.; Bolton, J. R. Water Research 2012 , $46,5672-5682$.

99. Souza, F. L., et al. Appl. Cat. B: Environmental 2013, 144, 121128.

100. Hiller, R.; Putterman, S. J.; Barber, B. P. Phys. Rev. Lett. 1992 , 69, 1182-1184.

101. Flannigan, D. J.; Suslick, K. S. Nature 2005, 434, 52-55.

102. Rooze, J., et al. Ultrasonics Sonochem. 2013, 20, 1-11.

103. Psillakis, E.; Mantzavinos, D.; Kalogerakis, N. Chemosphere 2004, 54, 849-857.

104. Mason, T. J.; Lorimer, J. P.; Walton, D. J. Ultrasonics 1990, 28, 333-337.

105. Cognet, P., et al. Ultrasonics Sonochem. 2000, 7, 163-167.

106. Lorimer, J. P., et al. Ultrasonics Sonochem. 2000, 7, 237-242.

107. Esclapez, M. D., et al. Ultrasonics Sonochem. 2010, 17, 10101020.

108. Hyde, M. E.; Compton, R. G. J. Electroanal. Chem. 2002, 531, 19-24.

109. Walton, D. J., et al. Synth. Commun. 1990, 20, 1843-1852.

110. Osawa, S., et al. Synthetic Metals 1987, 18, 145-150.

111. Saterlay, A. J.; Compton, R. G. Fresen. J. Anal. Chem. 2000, 367, 308-313.

112. Compton, R. G.; Eklund, J. C.; Marken, F. Electroanalysis 1997, 9, 509-522.

113. Babuponnusami, A.; Muthukumar, K. Chem. Eng. J. 2012, 183, 1-9.

114. Paddon, C. A., et al. Ultrasonics Sonochem. 2006, 13, 126132.

115. Chua, C.-Y.; Loh, K.-C. Can. J. Chem. Eng. 2008, 86, 739-746.

116. Takagami, N., et al. Electrochem. 2006, 74, 599-602.

117. Oturan, N.; Panizza, M.; Oturan, M. A. J. Phys. Chem. A 2009, 113, 10988-10993.

118. Oturan, N.; Brillas, E.; Oturan, M. A. Environm. Chem. Lett. 2012, 10, 165-170.

119. Lorimer, J. P., et al. Ultrasonics Sonochem. 2004, 11, 223-226.

120. Sanchez-Carretero, A., et al. Ind. Eng. Chem. Res. 2011, 50, 7073-7076.

121. Wang, J., et al. J. Haz. Mat. 2009, 166, 502-507.

122. Zhao, X. K., et al. J. Photochem. Photobiol. a-Chemistry. 2004, $161,215-220$.

123. Hou, Y., et al. J. Environm. Sci.-China. 2009, 21, 1321-1328.

124. Souza, F. L., et al. Ind. Eng. Chem. Res. 2013, 52, 9674-9682.

125. Panizza, M.; Cerisola, G. Electrochemical processes for the treatment of organic pollutants. New York: Nova Science, 2006.

126. Aquino, J. M., et al. J. Haz. Mat. 2011, 192, 1275-1282.

127. Costa, C. R., et al. J. Haz. Mat. 2010, 180, 429-435.

128. Costa, C. R., et al. J. Haz. Mat. 2008, 153, 616-627.

129. Costa, C. R.; Olivi, P. Electrochim. Acta 2009, 54, 2046-2052.

130. Panizza, M.; Cerisola, G. Environm. Sci. Technol. 2004, 38, $5470-5475$.
131. Rao, N. N., et al. J. Chem. Technol. Biotechnol. 2001, 76, 11241131.

132. Vlyssides, A. G., et al. Water Sci. Technol. 1997, 36, 271-278.

133. Vlyssides, A. G.; Israilides, C. J. Environm. Pollution 1997, 97, 147-152.

134. Israilides, C. J., et al. Bioresource Technology 1997, 61, 163170.

135. da Silva, A. J. C., et al. Chem. Eng. J. 2013, 233, 47-55.

136. Lakshmi Kruthika, N., et al. J. Environm. Chem. Eng. 2013, 1, 183-188.

137. Diaz, L. A.; Botte, G. G. Ind. Eng. Chem. Res. 2012, 51, $12167-$ 12172.

138. Goncalves, M. R.; Marques, I. P.; Correia, J. P. Water Research 2012, 46, 4217-4225.

139. Mohan, N.; Balasubramanian, N.; Basha, C. A. J. Haz. Mat. 2007, 147, 644-651.

140. Valero, D., et al. Environm. Sci. Technol. 2010, 44, 5182-5187.

141. Lahav, O., et al. Chem. Eng. J. 2013, 218, 214-222.

142. Chatzisymeon, E., et al. J. Haz. Mat. 2009, 167, 268-274.

143. Neelavann, M. G.; Revathi, M.; Basha, C. A. J. Haz. Mat. 2007, 149, 371-378.

144. Yavuz, Y.; Koparal, A. S.; Ogutveren, U. B. Desalination 2010, 258, 201-205.

145. Anglada, A., et al. Water Research 2011, 45, 828-838.

146. Canizares, P., et al. Chemosphere 2007, 67, 832-838.

147. Canizares, P., et al. J. Haz. Mat. 2006, 138, 173-181.

148. Linares-Hernandez, I., et al. J. Haz. Mat. 2010, 175, 688-694.

149. Montanaro, D.; Petrucci, E.; Merli, C. J. Appl. Electrochem. 2008, 38, 947-954.

150. Tsantaki, E., et al. J. Haz. Mat. 2012, 207, 91-96.

151. Dominguez, J. R., et al. Water Air and Soil Pollution 2012, 223, 2685-2694.

152. Souza, R. B. A.; Ruotolo, L. A. M. J. Environm. Chem. Eng. 2013, 1, 544-551.

153. Deligiorgis, A., et al. Water Research 2008, 42, 1229-1237.

154. Canizares, P., et al. J. Chem. Technol. Biotechnol. 2006, 81, 1331-1337.

155. Sales Solano, A. M., et al. Appl. Cat. B-Environmental 2013, 130, 112-120.

156. Chatzisymeon, E., et al. Water Research 2009, 43, 3999-4009.

157. Daghrir, R., et al. Sci. Total Environment 2014, 466-467, 300305.

158. Esquivel, K., et al. Water Research 2009, 43, 3593-3603.

159. Monteiro Paschoal, F. M.; Anderson, M. A.; Zanoni, M. V. B. J. Haz. Mat. 2009, 166, 531-537.

160. Anglada, A., et al. Catalysis Today 2010, 151, 178-184.

161. Van Hege, K.; Verhaege, M.; Verstraete, W. Water Research 2004, 38, 1550-1558.

162. Urtiaga, A., et al. J. Appl. Electrochem. 2012, 42, 779-786.

163. Szpyrkowicz, L.; Radaelli, M. J. Appl. Electrochem. 2006, 36, 1151-1156.

164. Szpyrkowicz, L. J. Chem. Technol. Biotechnol. 2006, 81, 13751383.

165. Parsa, J. B.; Shojaat, R. Phys. Chem. Liquids 2007, 45, 479485.

166. Can, O. T. Desal. Water Treatment 2013.

167. Deshpande, A. M.; Ramakant; Satyanarayan, S. J. Haz., Toxic, Radioactive Waste 2012, 16, 316-326.

168. Anglada, A.; Urtiaga, A.; Ortiz, I. Environm. Sci. Technol. 2009, 43, 2035-2040

169. Panizza, M.; Martinez-Huitle, C. A. Chemosphere 2013, 90, $1455-1460$

170. Diaz, V., et al. Water Research 2011, 45, 125-134.

171. Panizza, M.; Cerisola, G. Water Research 2006, 40, 11791184.

172. Gotsi, M., et al. Water Research 2005, 39, 4177-4187.

173. Un, U. T., et al. Chem. Eng. J. 2008, 139, 445-452. 
174. Zhu, X.; Ni, J.; Lai, P. Water Research 2009, 43, 4347-4355.

175. Zerbinati, O.; Pittavino, S. Environm. Sci. Poll. Res. 2003, 10, 395-398.

176. Sanchez, A., et al. Chem. Eng. J. 2013, 233, 8-13.

177. Li, Z., et al. Electrochim. Acta 2013, 102, 174-182.

178. Bashir, M. J. K., et al. Waste Management 2009, 29, 25342541.

179. Martinez-Huitle, C. A., et al. J. Electroanal. Chem. 2012, 674, 103-107.

180. Esquivel, K., et al. J. Appl. Electrochem. 2013, 43, 433-440.

181. Eslami, A., et al. J. Mazandaran Univer. Med. Sci. 2013, 23, 102-111.

182. Wang, H., et al. J. Harbin Inst. Technol. 2012, 44, 105-111.

183. Wang, B.; Gu, L.; Ma, H. J. Haz. Mat. 2007, 143, 198-205.

184. Atmaca, E. J. Haz. Mat. 2009, 163, 109-114.

185. Bellakhal, N., et al. Environm. Chem. 2006, 3, 345-349.

186. Tezcan Un, U.; Koparal, A. S.; Bakir Ogutveren, U. J. Haz. Mat. 2009, 164, 580-6.

187. Yavuz, Y., et al. J. Chem. Technol. Biotechnol. 2011, 86, 964969.

188. Zhang, H.; Zhang, D.; Zhou, J. J. Haz. Mat. 2006, 135, 106111.

189. Yavuz, Y. Sep. Purif. Technol. 2007, 53, 135-140.

190. Bensalah, N., et al. Clean-Soil Air Water 2013, 41, 635-644.

191. Virkutyte, J.; Rokhina, E.; Jegatheesan, V. Biores. Technol. 2010, 101, 1440-1446.
192. Khoufi, S.; Aloui, F.; Sayadi, S. Chem. Eng. Process. 2009, 48, 643-650.

193. Kurt, U.; Apaydin, O.; Gonullu, M. T. J. Haz. Mat. 2007, 143, 33-40.

194. Mohajeri, S., et al. J. Haz. Mat. 2010, 176, 749-758.

195. Aziz, H. A.; Othman, O. M.; Abu Amr, S. S. Waste Management 2013, 33, 396-400.

196. Lin, S. H.; Chang, C. C. Water Research 2000, 34, 4243-4249.

197. Ghosh, P.; Samanta, A. N.; Ray, S. Desalination 2011, 266, 213-217.

198. Akyol, A., et al. Sep. Purif. Technol. 2013, 112, 11-19.

199. Ting, W.-P.; Huang, Y.-H.; Lu, M.-C. React. Kin. Cat. Lett. 2007, 92, 41-48.

200. Wang, C.-T., et al. Desalination 2010, 253, 129-134.

201. Zarei, M., et al. J. Haz. Mat. 2010, 173, 544-551.

202. Farhadi, S., et al. J. Haz. Mat. 2012, 219, 35-42.

203. Salari, D., et al. J. Electroanal. Chem. 2009, 629, 117-125.

204. Zhao, X., et al. Biores. Technol. 2010, 101, 865-869.

205. Altin, A. Sep. Purif. Technol. 2008, 61, 391-397.

206. Sundarapandiyan, S., et al. Water Environm. Res. 2009, 81, 319324.

207. Ai, Z., et al. Ultrasonics Sonochem. 2010, 17, 370-375.

208. Orescanin, V., et al. J. Environm. Sci. Health Part a-Toxic/ Hazardous Substances \& Environmental Eng. 2013, 48, 15431547.

209. Sahinkaya, S. J. Ind. Eng. Chem. 2013, 19, 601-605. 